\title{
Silicic, high- to extremely high-grade ignimbrites and associated deposits from the Paraná Magmatic Province, southern Brazil
}

\author{
Ana Carolina F. Luchetti ${ }^{\mathrm{a}, *}$, Antonio J.R. Nardy ${ }^{\mathrm{a}}$, José Madeira ${ }^{\mathrm{b}}$ \\ a Instituto de Geociências e Ciências Exatas, Universidade Estadual Paulista (UNESP), Rio Claro, SP 13506-900, Brazil \\ ${ }^{\mathrm{b}}$ Faculdade de Ciências and Instituto Dom Luiz, Universidade de Lisboa, Portugal
}

\section{A R T I C L E I N F O}

\section{Article history:}

Received 31 July 2016

Received in revised form 28 September 2017

Accepted 12 November 2017

Available online 13 November 2017

\section{Keywords:}

Paraná Magmatic Province

Silicic volcanism

High-grade ignimbrites

Low explosivity eruptions

\begin{abstract}
A B S T R A C T
The Cretaceous trachydacites and dacites of Chapecó type (ATC) and dacites and rhyolites of Palmas type (ATP) make up $2.5 \%$ of the $~ 800.000 \mathrm{~km}^{3}$ of volcanic pile in the Paraná Magmatic Province (PMP), emplaced at the onset of Gondwana breakup. Together they cover extensive areas in southern Brazil, overlapping volcanic sequences of tholeiitic basalts and andesites; occasional mafic units are also found within the silicic sequence. In the central region of the PMP silicic volcanism comprises porphyritic ATC-type, trachydacite high-grade ignimbrites (strongly welded) overlying aphyric ATP-type, rhyolite high- to extremely high-grade ignimbrites (strongly welded to lava-like). In the southwestern region strongly welded to lava-like high-grade ignimbrites overlie ATP lava domes, while in the southeast lava domes are found intercalated within the ignimbrite sequence. Characteristics of these ignimbrites are: widespread sheet-like deposits (tens to hundreds of km across); absence of basal breccias and basal fallout layers; ubiquitous horizontal to sub-horizontal sheet jointing; massive, structureless to horizontally banded-laminated rock bodies locally presenting flow folding; thoroughly homogeneous vitrophyres or with flow banding-lamination; phenocryst abundance presenting upward and lateral decrease; welded glass blobs in an 'eutaxitic'-like texture; negligible phenocryst breakage; vitroclastic texture locally preserved; scarcity of lithic fragments. These features, combined with high eruption temperatures $\left(\geq 1000^{\circ} \mathrm{C}\right)$, low water content $(\leq 2 \%)$ and low viscosities $\left(10^{4-7} \mathrm{~Pa} \mathrm{~s}\right)$ suggest that the eruptions were characterized by low fountaining, little heat loss during collapse, and high mass fluxes producing extensive deposits.
\end{abstract}

(c) 2017 Published by Elsevier B.V.

\section{Introduction}

Large igneous provinces (LIPs) have been the focus of many studies (e.g. Mahoney and Coffin, 1997; Ernst et al., 2005; Bryan and Ernst, 2008; White et al., 2009; Bryan and Ferrari, 2013) as they record the largest basaltic and silicic eruptions on Earth (Bryan et al., 2010) directly related to the fragmentation of continents and supercontinents (Bryan and Ferrari, 2013) and, possibly with mass extinction events (e.g. Wignall, 2001; White and Saunders, 2005). The Paraná-Etendeka Magmatic Province (PMPE) is one of the largest known CFB (Continental Flood Basalts), with $1,000,000 \mathrm{~km}^{3}$ of volcanic rocks (Melfi et al., 1988; Peate, 1997), preceding the breakup of Gondwana and the subsequent opening of the South Atlantic Ocean. It is also characterized by a large volume of silicic volcanism (Milner et al., 1995; Bellieni et al., 1986; Garland et al., 1995; Nardy et al., 2008) and huge silicic eruptions some of which exceeding $8000 \mathrm{~km}^{3}$ (Milner et al., 1992; Bryan et al., 2010).

\footnotetext{
* Corresponding author.

E-mail address: caroluch@unesp.br (A.C.F. Luchetti).
}

The extent and unusual features of the Paraná silicic volcanic deposits make them unique in the global geological record and their mode of emplacement has been the subject of controversy. Some authors consider them to be pyroclastic flows (Whittingham, 1989; Bellieni et al., 1986; Milner et al., 1992; Garland et al., 1995; Bryan et al., 2010), while others interpret them as lava flows and/or domes (Garland et al., 1995; Umann et al., 2001; Waichel et al., 2012; Polo and Janasi, 2014; Polo et al., 2017, in press).

The problem in distinguishing between lava flows and ignimbrites is the lack or non-preservation of primary pyroclastic textures such as pumice lapilli, fiamme, glass shards, broken phenocrysts, degassing pipes, and lithic fragments. According to Henry and Wolff (1992) the base and/or top of such units are key places for this recognition, since lava flows usually display thick upper and basal autobreccias (Bonnichsen and Kauffman, 1987) which are uncommon in ignimbrites. Likewise pyroclastic features would be more likely preserved in these parts due to quenching (Henry and Wolff, 1992). However the base and top of these silicic units are often hidden, weathered or have been eroded. Furthermore pyroclastic deposits can be intensely welded from bottom to top (Ross and Smith, 1961) or may have undergone 
rheomorphism, which can completely obliterate explosive features; in this case the terms 'high- to extremely high- grade' or 'lava-like' are applied (Branney et al., 1992; Branney and Kokelaar, 1992, 2002). Therefore, the lack of primary pyroclastic textures does not indicate a lava flow nature of the volcanic body, especially for such old deposits where very few pristine are preserved. Many other works in the literature focus on the subtle differences and complexities between lavas and lava-like ignimbrites in terms of their eruption processes, deposition, welding and rheomorphism, and field characteristics (e.g. Schmincke and Swanson, 1967; Wolff and Wright, 1981; Walker, 1983; Henry et al., 1988; Branney et al., 2008; Freundt and Schmincke, 1995; Freundt, 1998; Kobberger and Schmincke, 1999; Sumner and Branney, 2002). Unit extension is also a striking feature, with ignimbrites reaching hundreds of $\mathrm{km}$ in length while extensive silicic lavas seldom reach tens of km (Bonnichsen and Kauffman, 1987; Branney et al., 2008).

Thus, the aim of this work was to characterize the extensive silicic sheets from the Paraná Magmatic Province (PMP) in order to discuss possible emplacement models, combining field information (stratigraphy, structures and textures) with mineralogical and geochemical data. The later include temperature, pressure and volatile content $\left(\mathrm{H}_{2} \mathrm{O}\right)$ estimates based on the mineral-liquid equilibrium in the attempt to constrain magmatic conditions prior to eruption.

\section{Geological setting}

The Paraná Magmatic Province (PMP) comprises the volcanic sequences included in the Serra Geral Formation. They cover $1,000,000 \mathrm{~km}^{2}$, with an average thickness of $650 \mathrm{~m}$ and a volume exceeding $800,000 \mathrm{~km}^{3}$ (Melfi et al., 1988). Flood basalts constitute about $90 \%$ of the total volume, whereas intermediate (basaltic-andesites and andesites) and silicic rocks make up 7 and $2.5 \%$, respectively (Bellieni et al., 1984; Piccirillo and Melfi, 1988). However, these correspond to minimum volumes, since considerable erosion (up to $2 \mathrm{~km}$ ) affected the South American Platform (Gallagher et al., 1994). Furthermore, part of this volcanism is also preserved on the African Continent, in the Etendeka (Namibia), Kwanza and Namibe (Angola) basins (Alberti et al., 1992; Milner et al., 1995; Marsh et al., 2001), giving rise to the Paraná-Etendeka Large Igneous Province (LIP). In Brazil the PMP volcanics were emplaced on aeolian sandstones of the Botucatu Formation in the Paraná Basin.

Based on geochemistry and spatial distribution, Bellieni et al. (1984) subdivided the Paraná Basin into three main regions: (1) southern, comprising the tholeiitic suite lying south of the Uruguay River alignment; (2) northern, including the tholeiitic-transitional rocks lying north of the Piquiri River alignment; and (3) central, the sequences located between those two alignments (Fig. 1).

${ }^{40} \mathrm{Ar} /{ }^{39} \mathrm{Ar}$ ages of volcanic rocks from the Serra Geral Formation range from 133.6 to $131.5 \mathrm{Ma}$ in its northern sector, and from 134.6 to 134.1 Ma in the south (Turner et al., 1994; Renne et al., 1992, 1996a, 1996b; Ernesto et al., 1999; Mincato et al., 2003; Thiede and Vasconcelos, 2010; Pinto et al., 2010). In addition, Janasi et al. (2011), using $\mathrm{U} / \mathrm{Pb}$ ratios from baddeleyite-zircon crystals in Chapecó-type rocks, determined by ID-TIMS, obtained an age of $134.3 \pm 0.8 \mathrm{Ma}$. These ages indicate a duration of the volcanism of around $3 \mathrm{Ma}$, which is consistent with paleomagnetic data presented by Marques and Ernesto (2004).

The silicic sequences are classically subdivided into two main types based in Ti content. Chapecó-type rocks (ATC) include porphyritic, crystal-rich, high-Ti dacites and trachydacites, preserved mainly north of the Uruguay River alignment, and a few outcrops south of the Uruguay River alignment (Fig. 1). They currently cover an area of $\sim 6000 \mathrm{~km}^{2}$ with a total volume of $\sim 1000 \mathrm{~km}^{3}$. Palmas-type rocks (ATP) include fine-grained, crystal-poor, low-Ti dacites and rhyolites that are spatially and volumetrically more significant than ATC rocks. They lie mainly in the southern region currently covering an area of $\sim 35,000 \mathrm{~km}^{2}$ corresponding to a total volume of $\sim 12,000 \mathrm{~km}^{3}$, while smaller units $\left(\sim 5000 \mathrm{~km}^{2}\right.$ and $\left.\sim 700 \mathrm{~km}^{3}\right)$ crop out in the central region (Fig. 1).

The ATP and ATC were further divided in subtypes based on $\mathrm{TiO}_{2}$ and $\mathrm{P}_{2} \mathrm{O}_{5}$ contents (see Fig. 2; Peate et al., 1992; Garland et al., 1995; Nardy et al., 2008): ATP-type rocks include Santa Maria (SM), Caxias do Sul (CS), Anita Garibaldi (AG), Jacuí (JC) and Clevelândia (CLV) sub-types; ATC-type rocks include Guarapuava (GPV), Ourinhos (OU) and Tamarana (TM) sub-types.

\section{Methods}

Field characterization was based on sections exposed along road cuts (see locations in Fig. 1) where these rocks were sampled and stratigraphic relationships, rock structures, textures documented.

Whole rock data were obtained from a set of 250 samples of unaltered rocks. Major elements analysis was carried out at the UNESP laboratories, using X-ray fluorescence spectrometry using fusion beads (1:10 lithium tetraborate). All methodology (including errors) is described in Nardy et al. (1997). The determination errors based on the concentration of 23 international certified references materials (AGV1, B-R, BCR-1, BE-N, BHVO-1, BIR-1, BX-N, DNC-1, DR-N, DTS-1, G-2, G-A, GBW-12, G-H, JA-1, JA-2, JB-2, JB-3, JGB-1, MRG-1, QLO-1, RGM-1, $\mathrm{W}-2)$ are: $\mathrm{Si}(0.52 \%), \mathrm{Ti}(1.92 \%), \mathrm{Al}(1.10 \%), \mathrm{Fe}$ (1.00\%), $\mathrm{MnO}(4.73 \%)$, $\mathrm{MgO}$ (1.05\%), Ca (1.56\%), Na (1.55\%), K (1.88\%) and P (2.99\%).

Mineral assemblage phases (plagioclase and pyroxene) were analysed in a JEOL-JXA 8230 Superprobe at UNESP, using 15kv of acceleration voltage, beam current of $20 \mathrm{nA}$, and a spot of $10 \mu \mathrm{m}$; 2 sigma standard errors based on counting statistics, taking into account peak and background measurements. The matrix correction was carried out online by JEOL software, using ZAF. The standards with mean standard deviations are: (I) plagioclase - Si (wollastonite- ${\mathrm{P} \& \mathrm{H}^{1}}^{1}, \pm 0.56 \%$ ), $\mathrm{Al}$ (anortite-SMS $^{2}, \pm 0.68$ ), Fe (ilmenite-PCMS ${ }^{3}, \pm 0.86$ ), Ca (wollastonite-P\&H, $\pm 0.36 \%$ ), Na (albite-P\&H, $\pm 1.66 \%$ ), $\mathrm{K}$ (orthoclase-P\&H, \pm $1.64 \%$ ); (II) pyroxene - Si (orthoclase-P\&H, $\pm 0.52 \%$ ), Ti (ilmenite-SMS, $\pm 0,42 \%$ ), $\mathrm{Al}$ (anotite-SMS, $\pm 0.68 \%$ ), Fe (ilmenite-PMCS, \pm 0.86 ), $\mathrm{Mn}$ (rhodonite, $\pm 0,80 \%$ ), $\mathrm{Mg} \quad$ (diopside-P\&H, $\pm 1,08 \%$ ), Ca (wollastonite_P\&H, $\pm 0.72 \%$ ), Na (albite-P\&H, $\pm 1,63 \%$ ). K (orthoclase$\mathrm{P} \& \mathrm{H}, \pm 1,26 \%$ ) e $\mathrm{Cr}$ (chromite-P\&H, $\pm 0.26 \%$ ). Mineral analyses and respective bulk rock compositions are available as Supplementary material.

\section{Volcanic deposits}

\subsection{Stratigraphy}

The silicic volcanic rocks constitute the upper part of the PMP volcanic succession, overlapping tholeiitic basalt and andesite lava flows. Occasional basalt and andesite also occur interlayered within the silicic sequences in the southern region (see columnar sections in Fig. $1^{\prime}$ ).

The central region, between Guarapuava (PR) and Campina da Alegria (SC), is the only place where ATC and ATP rocks occur simultaneously allowing to observe their stratigraphic relation. At least two ATP sheets (Clevelândia subtype) underlie ATC rocks (Guarapuava subtype; see sections MA5, MA6, CA and MA4 in Fig. 3) and both silicic units are locally overlapped by basalts. The morphology of the region is characterized by gently undulating flat surfaces (plateaus) and variable alteration thicknesses. In this region the outcrops are discontinuous and the elevation at which the contacts between the ATP and ATC units occur may vary up to $375 \mathrm{~m}$, reflecting differential vertical movements probably related to the breakup of Gondwana.

\footnotetext{
1 P\&H Developments LTD.

2 Smithsonian Microbeam Standards.

McSwiggen \& Associates, USA.
} 


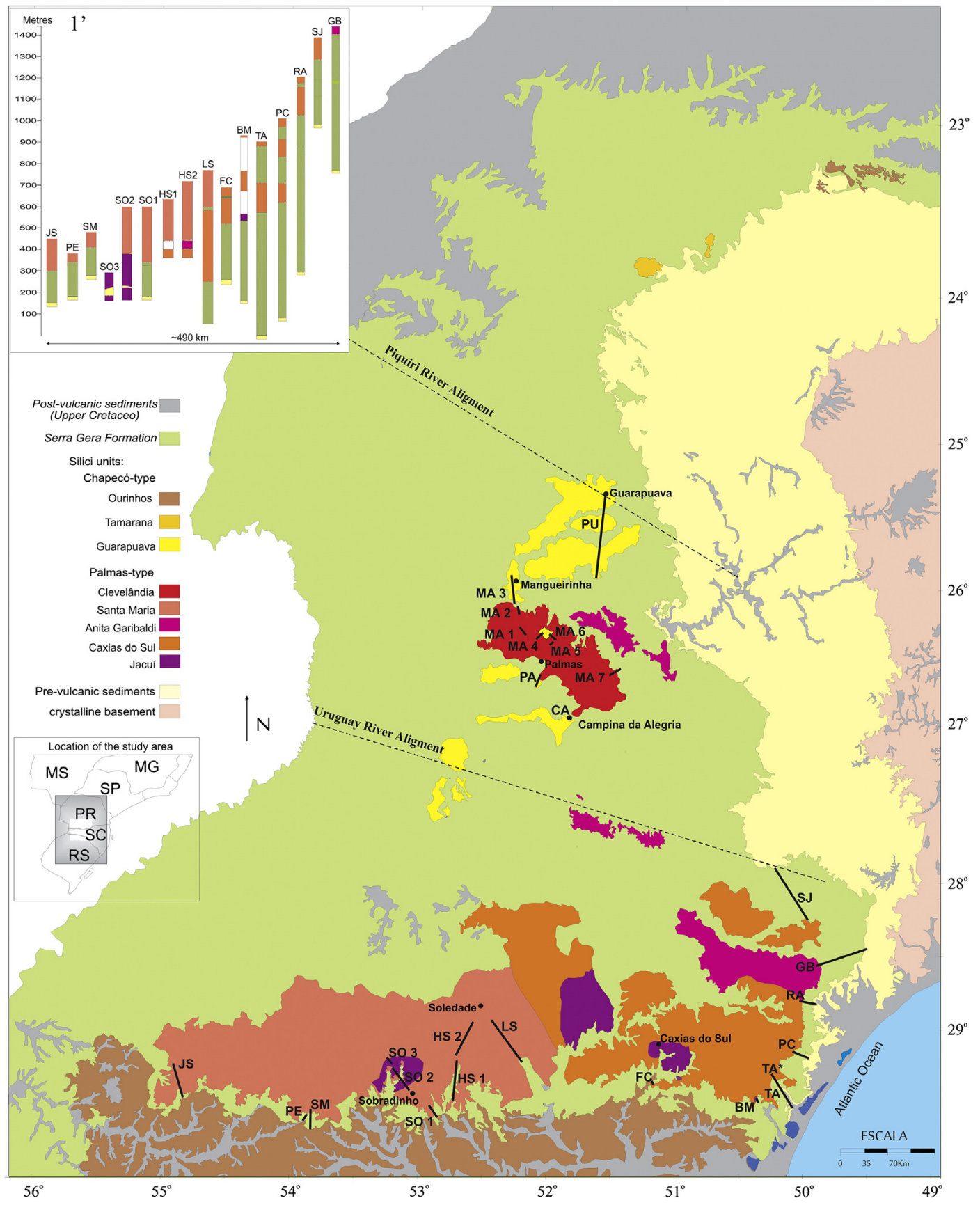

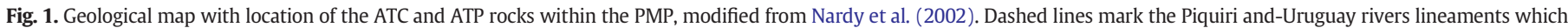

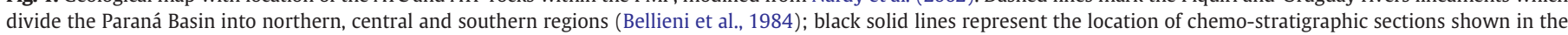
insertion $1^{\prime}$ (southern region) and Figs. 3-4.

In the southern region, ATP rocks are dominant. As in the central region, the relief is characterized by extensive flat surfaces with gently undulating tabular tops. The geological sections (Fig. $1^{\prime}$ ) reveal that the ATP subtypes are arranged in a stratigraphic sequence. The Santa Maria subtype sequence overlaps all other ATP subtypes (sections SO2, HS1, HS2 and LS, Fig. 4), indicating this type of magma was the last to be erupted. In turn, Jacuí subtype sequence underlies Caxias do Sul subtype rocks (section BM, Fig. $1^{\prime}$ ) indicating that it was the earliest magma erupted.

Towards the west, near Sobradinho, the Jacuí subtype sequence lies directly on top of a 40 m-thick Botucatu sandstone sequence (sections SO2 and SO3, Fig. 4), whose base was intruded by an ATP magma body (Jacuí subtype?) generating a peperite.
Peperites are frequently found at the base and interlayered within the silicic volcanic sequence (Luchetti et al., 2014), indicating periods of subaerial sedimentation before and between the silicic volcanic eruptions.

\subsection{Lava domes}

Silicic lava domes are often found at the base of the silicic sequences in the southern region (western portion; sections SO 1-3, HS 1-2 and LS; Fig. 4) or locally overlying high-grade ignimbrite sheet (eastern portion; section TA; Fig. 4). They form clusters of pitchstone outcrops, 40 to $190 \mathrm{~m}$-thick and with limited horizontal extension, with vesicular outer layers enveloped by partially matrix-supported breccias (Fig. 5a-b). 


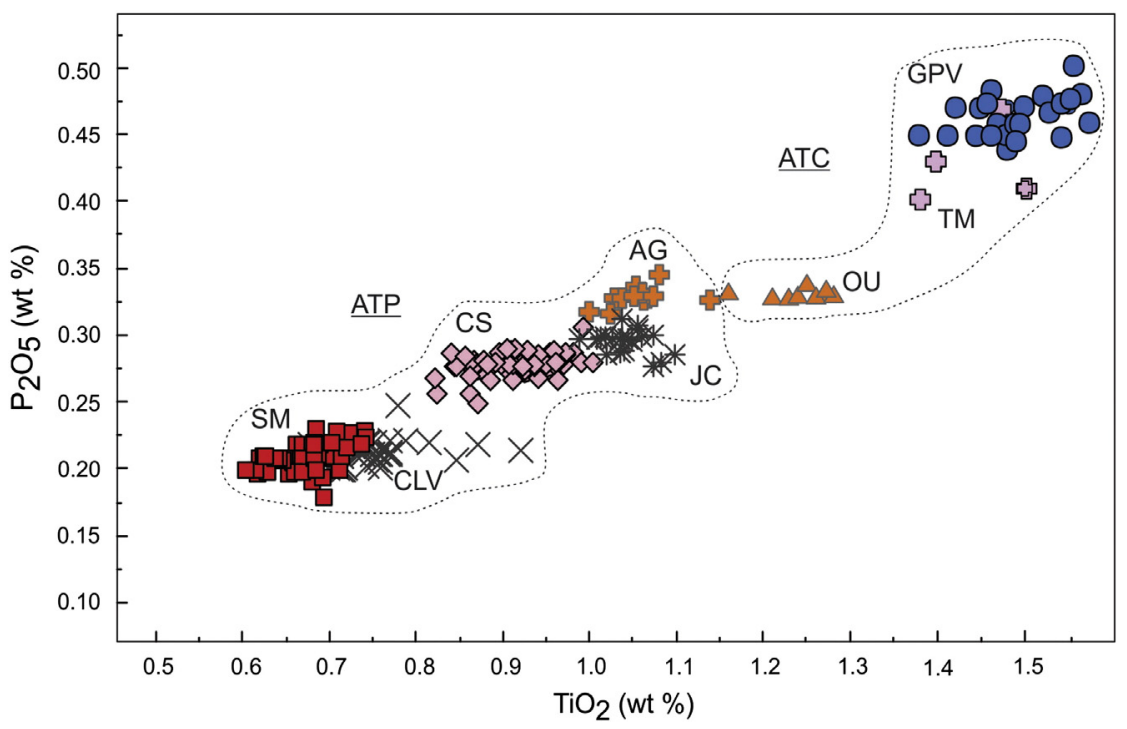

Fig. 2. $\mathrm{TiO}_{2} \times \mathrm{P}_{2} \mathrm{O}_{5}$ (wt\%) plot characterizing the different subtypes for the ATC and ATP rocks.

Breccias comprise dominantly angular, vesicular to dense clasts of the same composition ranging from centimetric blocks to millimetric clasts. The breccia elements are altered to beige, light or dark green colours, clasts present perlitic fractures and spherical to stretched vesicles, often filled by quartz or other silica minerals.

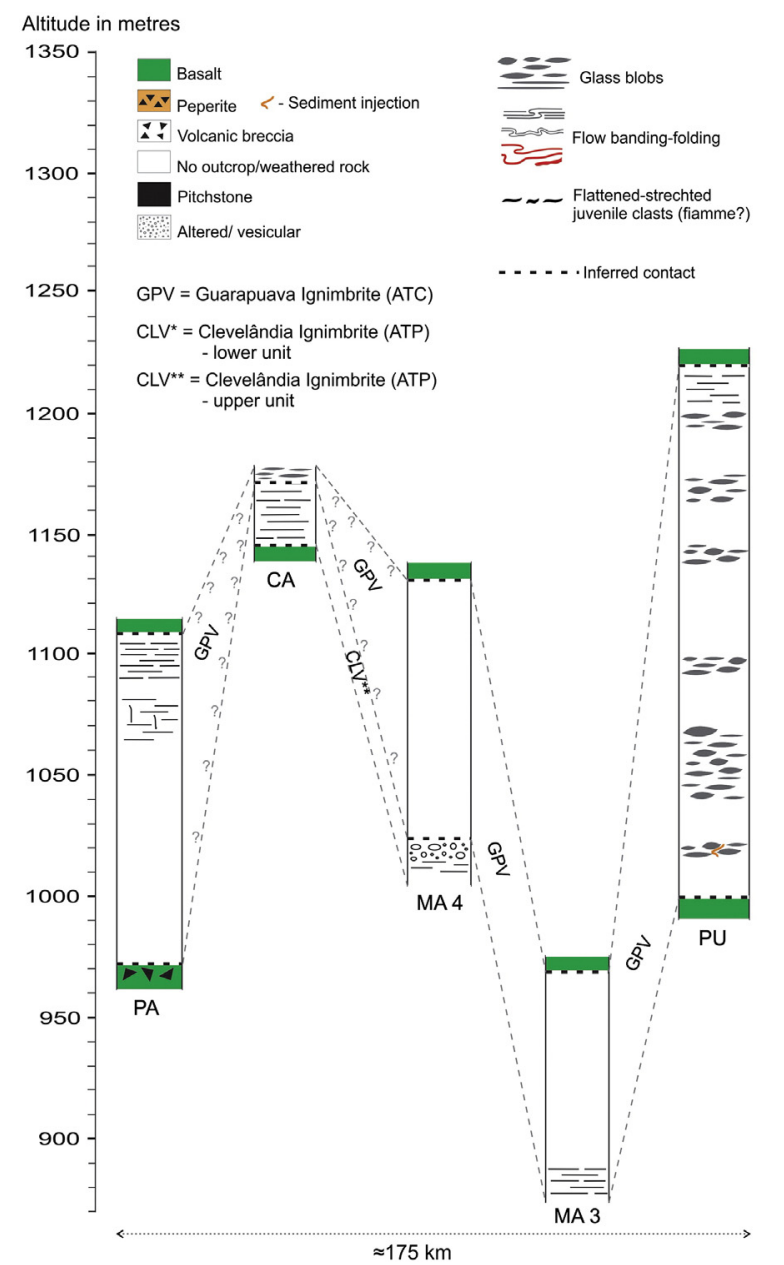

Basal breccias may present a matrix made up of unsorted finegrained sediment corresponding to a peperitic interaction with underlying sediment (Luchetti et al., 2014). Pitchstone outcrops usually present a massive structure. However, devitrified domains display conspicuous horizontal to platy joints, with spacing increasing inwards

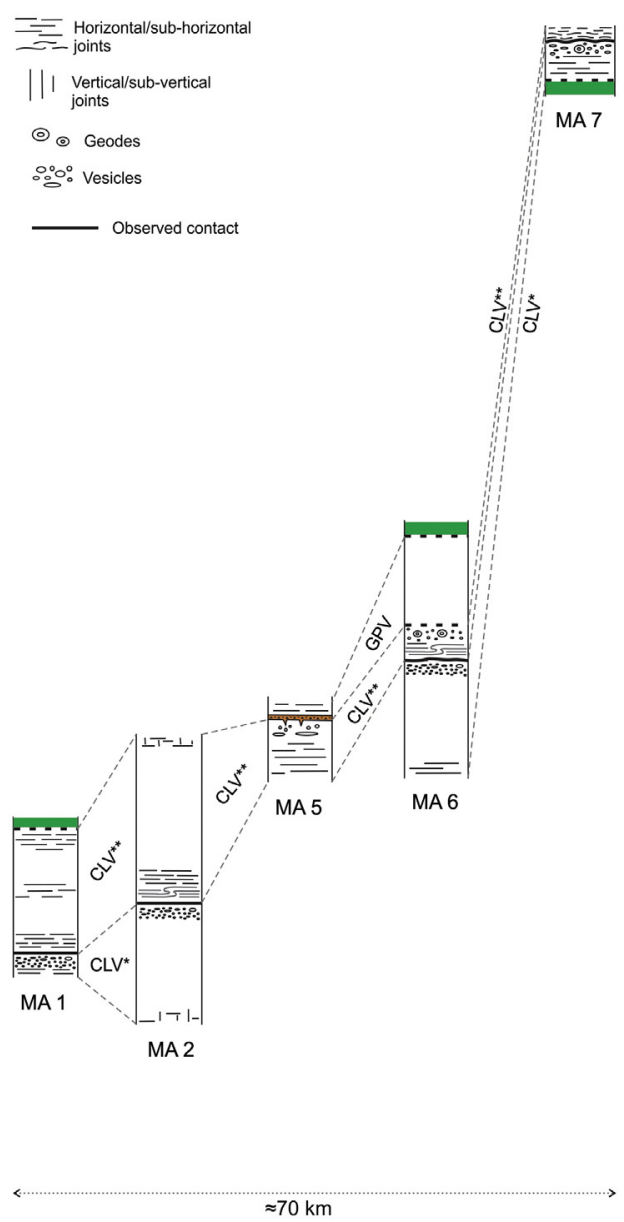

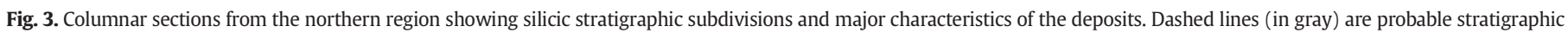
correlations. Location of sections indicated in Fig. 1. 


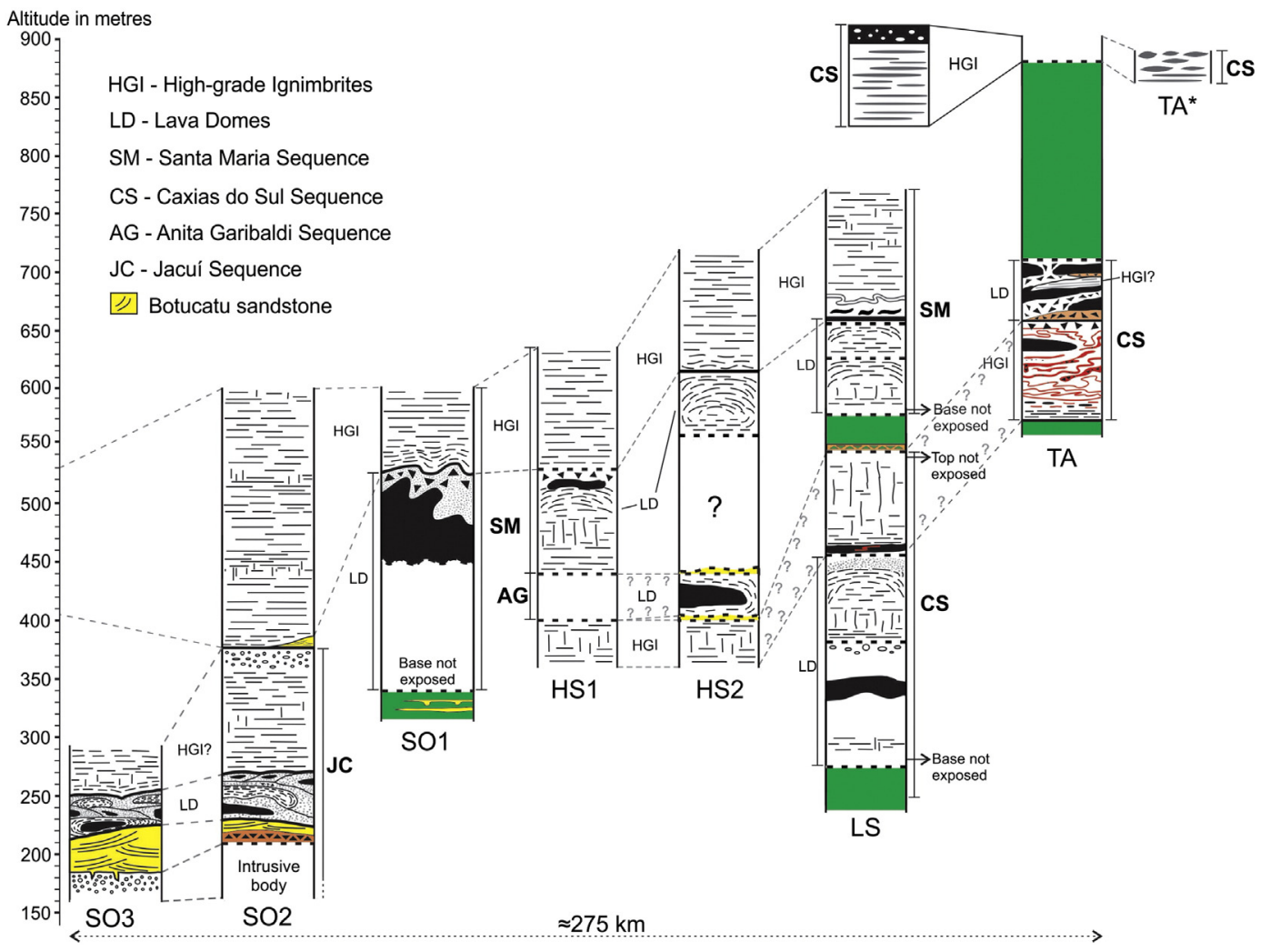

Fig. 4. Columnar sections from the southern region showing silicic stratigraphic subdivisions and major characteristics of the deposits. Location of sections indicated in Fig. 1.

(Fig. 5c). Joints can be curved - corresponding to concentric jointing mainly in the outer parts of small lobes. Thicker units consist of a massive pitchstone interior surrounded by horizontal-to-curved sheeted jointed devitrified rock, usually weathered and locally brecciated glassy outer portions. Small lobate shapes are common, presenting massive glassy interior and altered or oxidized, vesicular to devitrified exterior.

At the western outcrops, near Sobradinho, lava domes directly overlap a 35 m-thick sequence of aeolian sandstone (a paleo-dune) of the
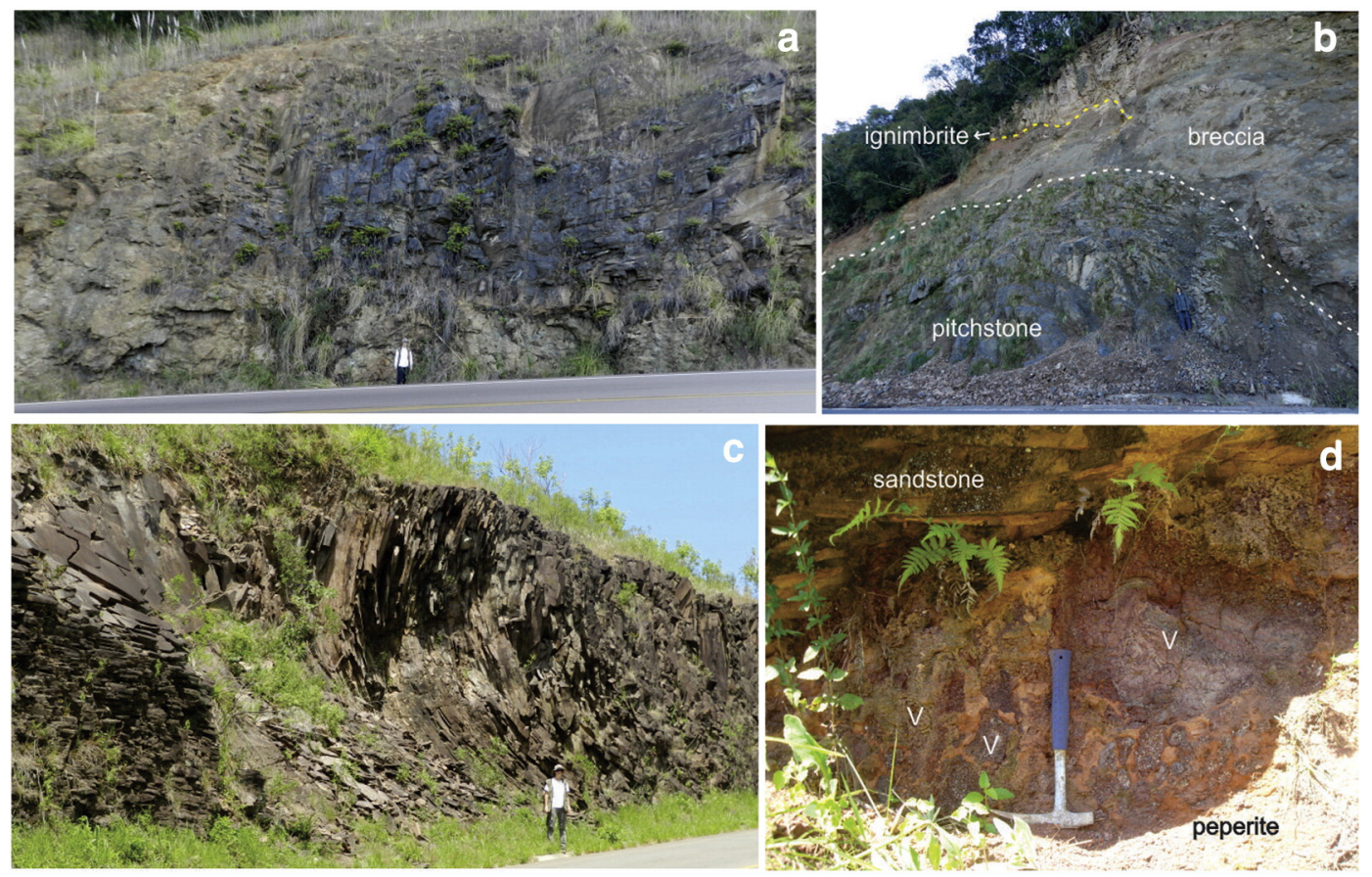

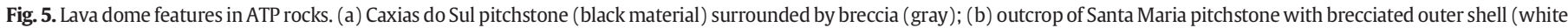

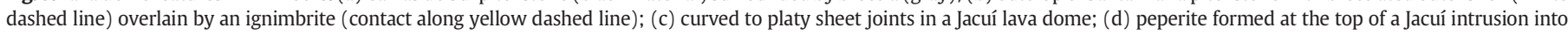
Botucatu Fm. sandstone; vesicles in the volcanic clasts (V) are oriented upwards and the sandstone matrix is also vesiculated. 
Botucatu Formation whose base is intruded by a silicic body locally forming peperites (Fig. 5d). The vesicles-amygdales in the volcanic clasts forming the peperite are upward oriented; the sandstone matrix also contains vesicles indicating that it was wet and unconsolidated and that the heat transfer from the interaction with the volcanic material produced vaporization of the sediment water. The groundmass of the intrusive body is holocrystalline and coarser when compared to the upper glassy lava domes, in agreement with slower cooling due to its intrusive nature.

\subsection{Extensive sheets - high- to extremely high-grade ignimbrites}

Extensive sheets occur in the central and southern regions of the PMP (Figs. 3-4) as flat-topped terraces, corresponding to structural surfaces in a constructional architecture formed by multiple, sub-parallel, tabular units. Maximum preserved thickness for the whole ATP sequence is $\sim 630 \mathrm{~m}$. However, the sequence must have been much thicker since the top was eroded and the base is not exposed in the central region. These sheets can be traced laterally for tens to hundreds of kilometres, locally thickening in valleys and thinning down to $2 \mathrm{~m}$ across topographic highs. Because the source areas are unknown, the thickness and extension of proximal-distal ignimbrite sheets and total erupted volumes are very difficult if not impossible to estimate.

In the central region, between Guarapuava and Palmas, two Clevelândia subtype sheets totalizing $120 \mathrm{~m}$ thick, one of which (upper sheet) is up to $70 \mathrm{~m}$ thick, underlie a $220 \mathrm{~m}$ thick Guarapuava subtype unit (ATC). In the southern region, 70 to 220 m-thick Santa Maria subtype sheets are the youngest units, overlying all other silicic units and basalts in the western region. Caxias do Sul and Jacuí subtype sheets present thicknesses of 30 to $160 \mathrm{~m}$ and $130 \mathrm{~m}$, respectively.

Most of the remaining outcrops comprise homogeneous or subtly banded, structureless, glassy or devitrified rocks providing little information as to its emplacement mode. A conspicuous feature is the horizontal to sub-horizontal jointing with spacing ranging from a few centimetres (for which the term 'sheet joints' is appropriate; e.g. Bonnichsen and Kauffman, 1987; Andrews et al., 2008), resulting in flaggy outcrops in the field, to a few metres (Fig. 6). Occasionally, vertical joints are also present with spacing ranging from a few centimetres to several metres. In places, unweathered massive rock occurs interfingered with altered or weathered portions, suggesting local variations in welding and/or the presence of multiple flow units (Fig. 6e).

Since the top of the sheets is weathered or eroded, basal portions usually preserve more diagnostic textures. Basal breccias occur
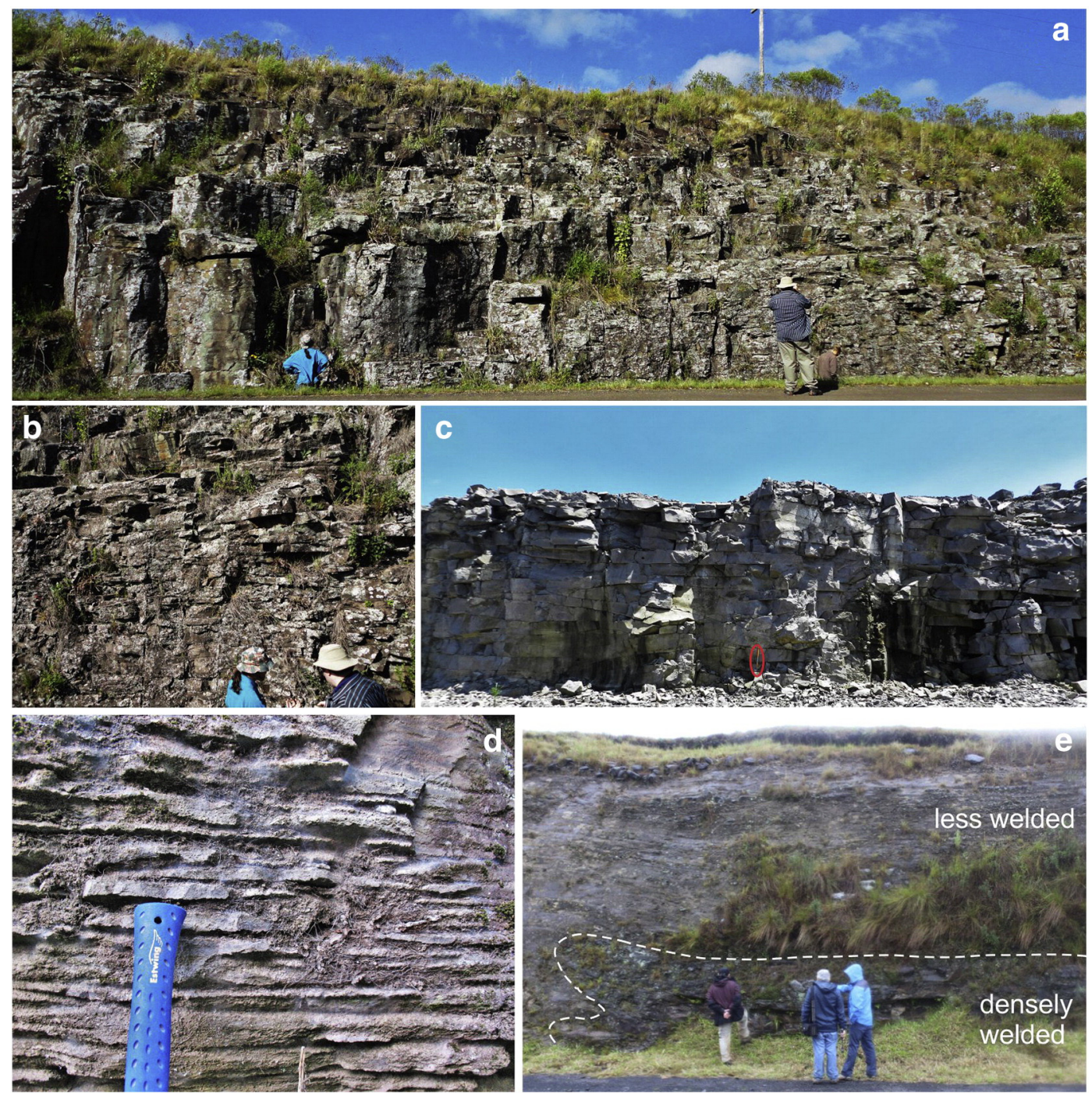

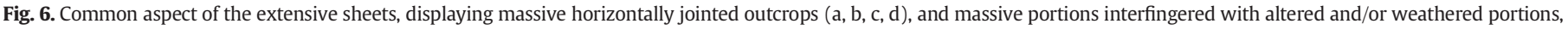

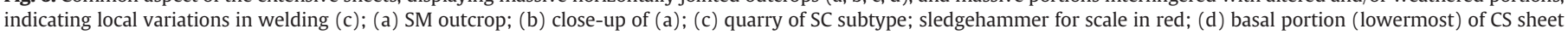
overlying basalt; note 'slabs' highlighted by the matrix alteration and removal. 
sporadically and frequently correspond to peperitic interaction (cf. Luchetti et al., 2014). Usually, the lowermost portions show a massive, sheeted (Fig. 6d) or horizontally thin banded rock. The bands, ranging in thickness from a few millimetres to several centimetres, correspond to alternation of microcrystalline, quartz-feldspar and glassy to spherulitic layers, locally deformed by small-scale isoclinal folds (Fig. 7a). In other places, lower banded portions (up to 10 m-thick) can be strongly contorted with complex folding (Fig. 7b, c). Upwards, banding becomes more laminar and normally base-parallel, and may be associated with parallel jointing, until it completely disappears in the innermost portions of the sheet. Oxidation is common, highlighted by red bands intercalated with dark gray ones (Fig. 7b, c), or by red juvenile clasts (Fig. 7g, h). Red portions can display post-depositional brecciation and hydraulic fracturing, with secondary minerals filling angular cavities and fractures. In some locations the contorted banding, associated with pitchstone pods or metre-sized bodies and top breccia, comprises the entire sheet.

Black vitrophyre zones (pitchstone) also occur at the base of Caxias do Sul and Santa Maria units. These are homogeneous or with contorted red flow banding or as 'vitrophyre-like' rock displaying lamination marked by millimetre-scale vesicles filled by quartz and reddish lenses which, in thin section, show a thoroughly devitrified-recrystallized groundmass. Glassy dark brown lenses show undulating margins and feathery terminations suggesting fiamme; however, their outlines are diffuse and locally overprinted by devitrification (Fig. 8a-b).

Another conspicuous feature observed in Guarapuava (ATC) and Caxias do Sul sheets (ATP) is a parataxitic-eutaxitic-like texture characterized by parallel, horizontal-to-sub-horizontal, dark lensshaped glass blobs (Fig. 7d-f) set in a light matrix (see Luchetti et al., 2017, this issue). In Caxias do Sul sheets, these blobs can be extremely flattened and stretched giving rise to centimetre-scale laminations or are intricately deformed by flow folding, indicating 'secondary mass flowage' (rheomorphism; Wolff and Wright, 1981).

A fumarole pipe-like structure was observed in a Guarapuava outcrop (Fig. 9), and concentrations of vesicles and amygdales in pipelike structures, similar to those reported in the Garth Tuff by McArthur et al. (1998), were also observed in Caxias do Sul contorted flow bands facies (Fig. 9). These structures were found at basal levels, near the contact with underlying sediment, and most vesicles/amygdales are stretched upwards.

The vitroclastic textures reported here were also found in basal portions of Santa Maria and Caxias do Sul sheets. In a Santa Maria outcrop, the rock is reddened by oxidation, horizontally jointed in places, and presents flattened-stretched to extremely flattened-stretched juvenile clasts (Fig. 7g, h) resembling collapsed pumices (fiamme). In thin section the matrix comprises plagioclase and Fe-Ti oxide crystals, numerous small plagioclase-pyroxene laths and stretched to extremely stretched glass shards (Fig. 8c-e). The latter are devitrified, deformed around the crystals-microlites while some shards still exhibit Y-shapes (Fig. 8d). The rock also presents strong millimetre-to-centimetre thick flow banding that is locally folded; in this case glass shards are no longer recognizable and laths are oriented parallel to flow banding (Fig. 8f). Upwards the sheet is massive and presents jointing sub-parallel to the banding. In Caxias do Sul outcrops, welded blocky, cuspate and Y-
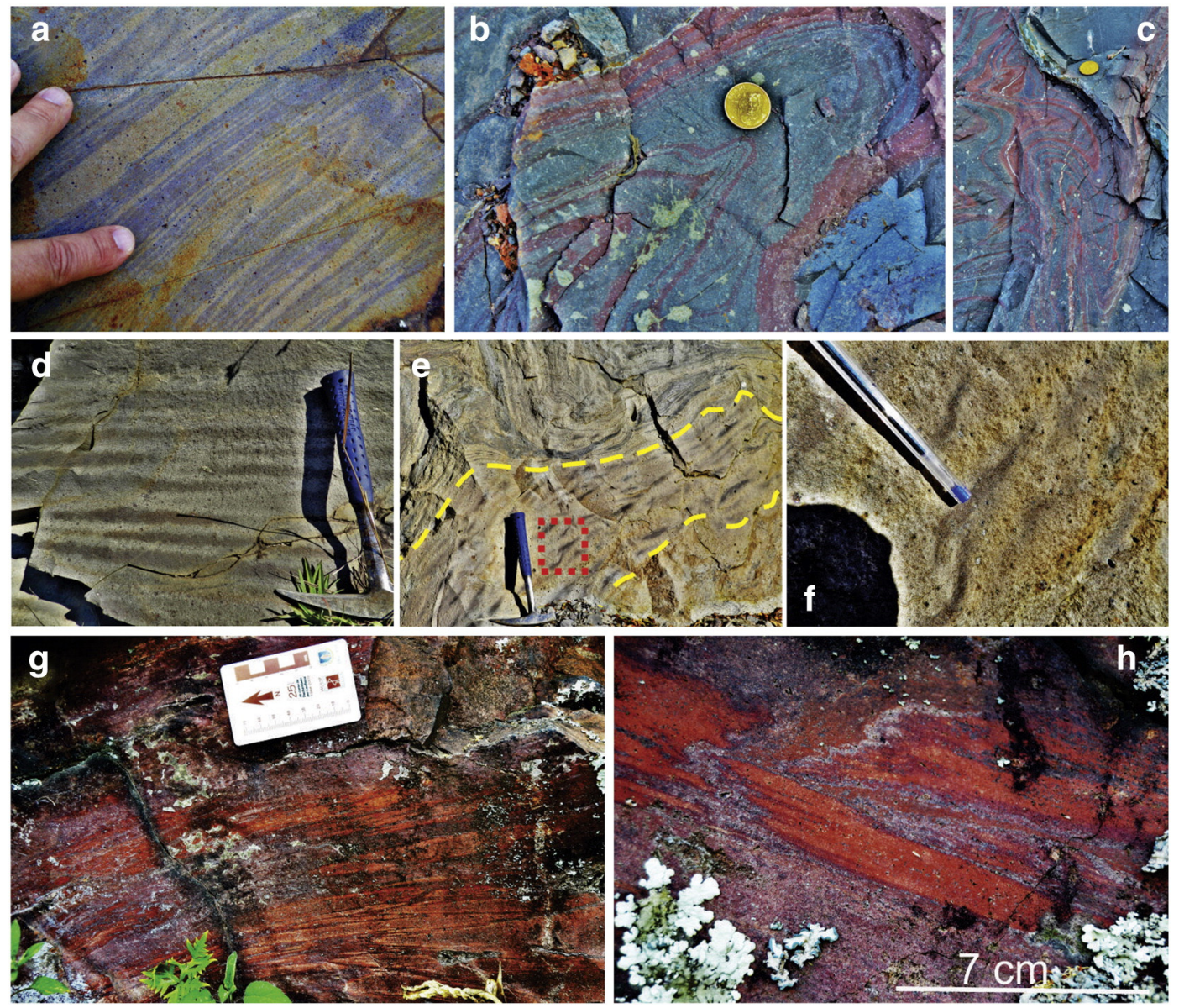

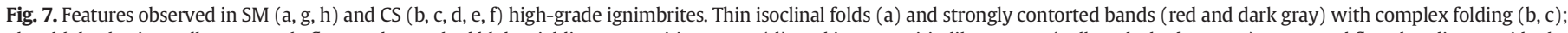

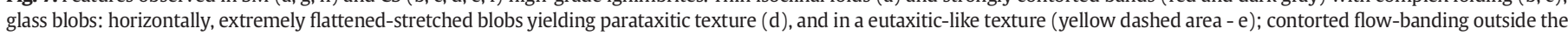
dashed area; (f) red dotted area in (e); oxidized (reddish) flattened-stretched juvenile clasts ( $\mathrm{g}$ ) with irregular-feathered boundaries (h - fiamme?). 

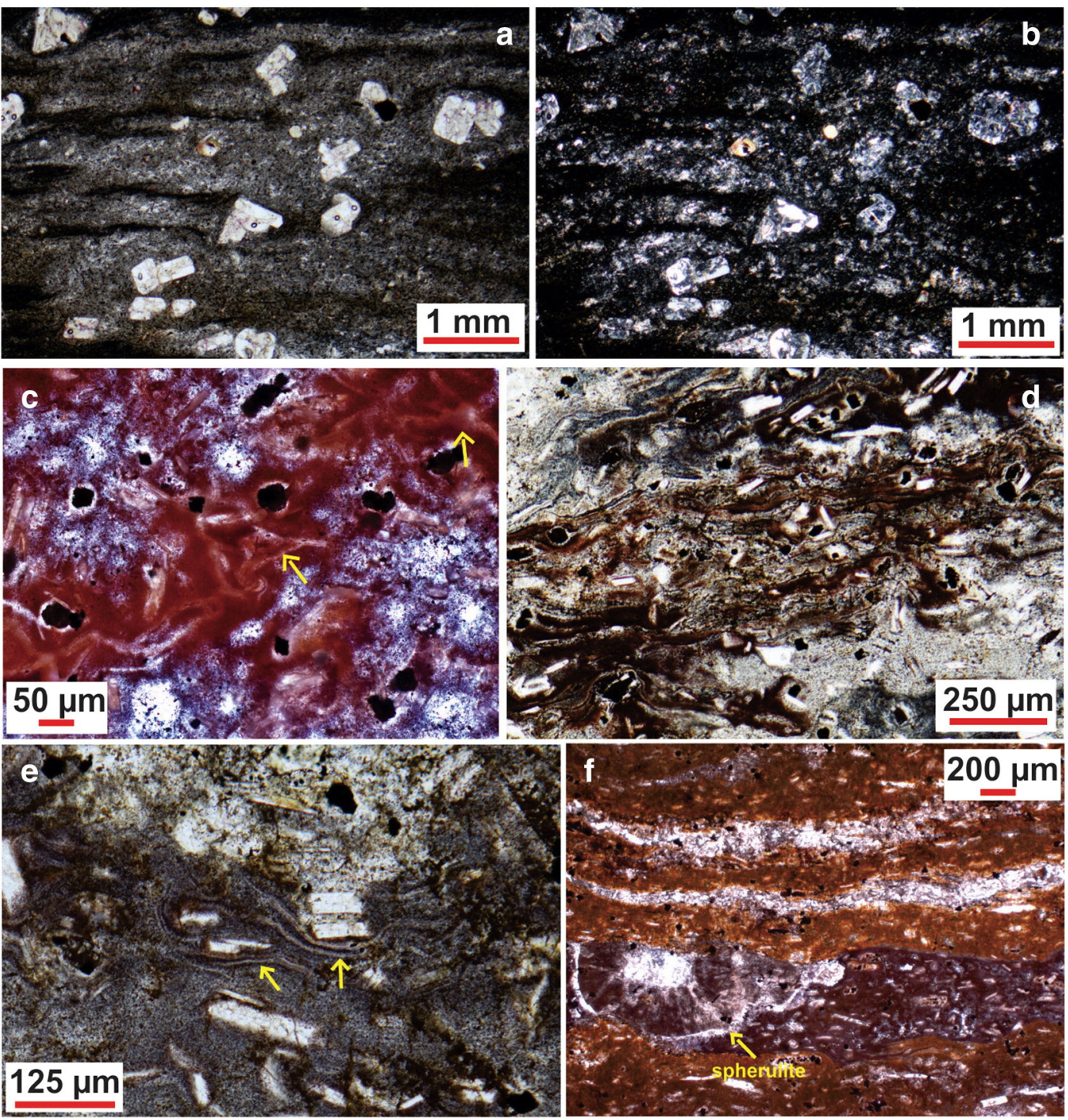

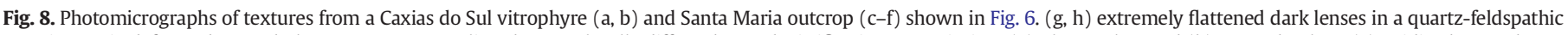

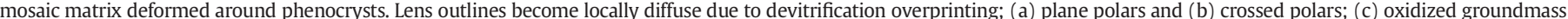

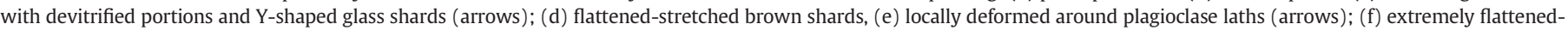

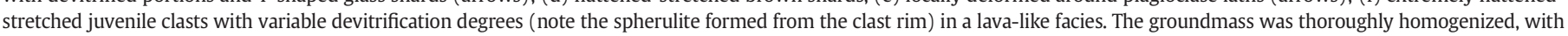
crystal laths oriented parallel to flow banding (plane polars).

shaped glass shards were observed in black vitrophyres (Fig. 10a-a' $-a^{\prime \prime}$, b-b') and flow banded rock (Fig. 10c- $\mathrm{c}^{\prime}$ ).

Remarkable vertical and lateral variation of phenocryst abundance suggests that the sheets may comprise multiple flow units. Santa Maria basal zones present up to 3\% of phenocrysts, while the top and westernmost zones are virtually phenocrysts-free. Caxias do Sul sheets may contain up to $5 \%$ of phenocrysts and become aphyric laterally. Although some phenocrysts are broken, breakage is not widespread even in the ATC rocks bearing large plagioclase phenocrysts. Broken phenocrysts are rare when compared with typical ignimbrites. The groundmass, characterized by passages from irregular glassy-cryptocrystalline portions into fine grained crystalline patches, gives a commonly mottled texture to the rocks.

The sheets also show varying abundance of spherical to ellipsoidal, millimetre- to centimetre sized vesicles and amygdales filled by quartz or calcite. Lithic fragments are rare, but where found, their composition is dominantly basalt-andesite, sometimes silicic, and occasionally granite; their shape may be angular, with well-defined limits, to rounded presenting diffuse contacts with the groundmass.
In the west, near Sobradinho town, the upper Jacuí subtype sheet, crops out for $\sim 25 \mathrm{~km}$ and comprises a massive, devitrified rock with a ubiquitous horizontal to sub-horizontal jointing.

\section{Mineralogy}

The studied ATC rocks (Guarapuava subtype) are porphyritic to sparsely porphyritic with up to $15 \%$ volume of plagioclase $\left(\mathrm{An}_{30-49}\right.$; Fig. 11), augite $\left(\mathrm{En}_{35-39} \mathrm{Wo}_{32-37}\right.$; Fig. 12$)$, pigeonite $\left(\mathrm{En}_{44-49} \mathrm{Wo}_{9-10}\right.$; Fig. 12), Fe-Ti oxides (Ti-magnetite and ilmenite) and apatite phenocrysts. Plagioclase crystals are up to $1 \mathrm{~cm}$ long and compose up to $10 \%$ volume of the rock. They are euhedral to sub-rounded with normal, inverse or oscillatory zoning and display embayments, corroded edges and pyroxene and $\mathrm{Fe}$-Ti oxides inclusions. Pyroxene crystals make up to $\sim 5 \%$ volume and rarely exceed $2 \mathrm{~mm}$ in length. They are subhedral, with rounded to irregular outlines, fractured, with corroded or reaction edges indicating resorption, and Fe-Ti oxides and apatite inclusions. FeTi oxides are represented by Ti-magnetite (37-96\% ulv) and ilmenite (74-97\% ilm) presenting subhedral to irregular shapes and 


\section{Pipe-like structures}

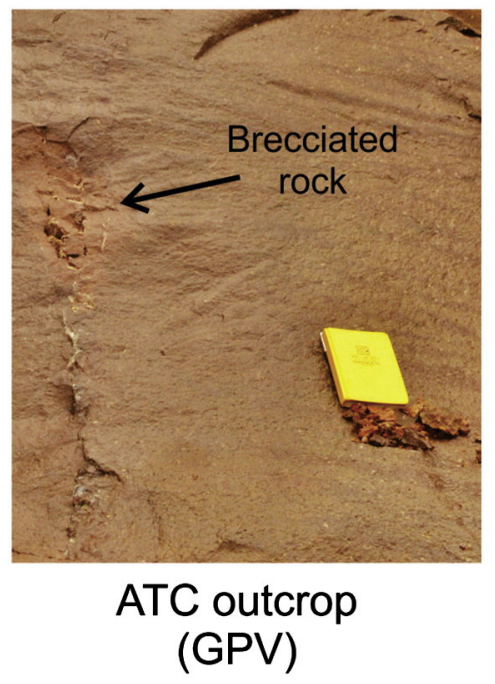

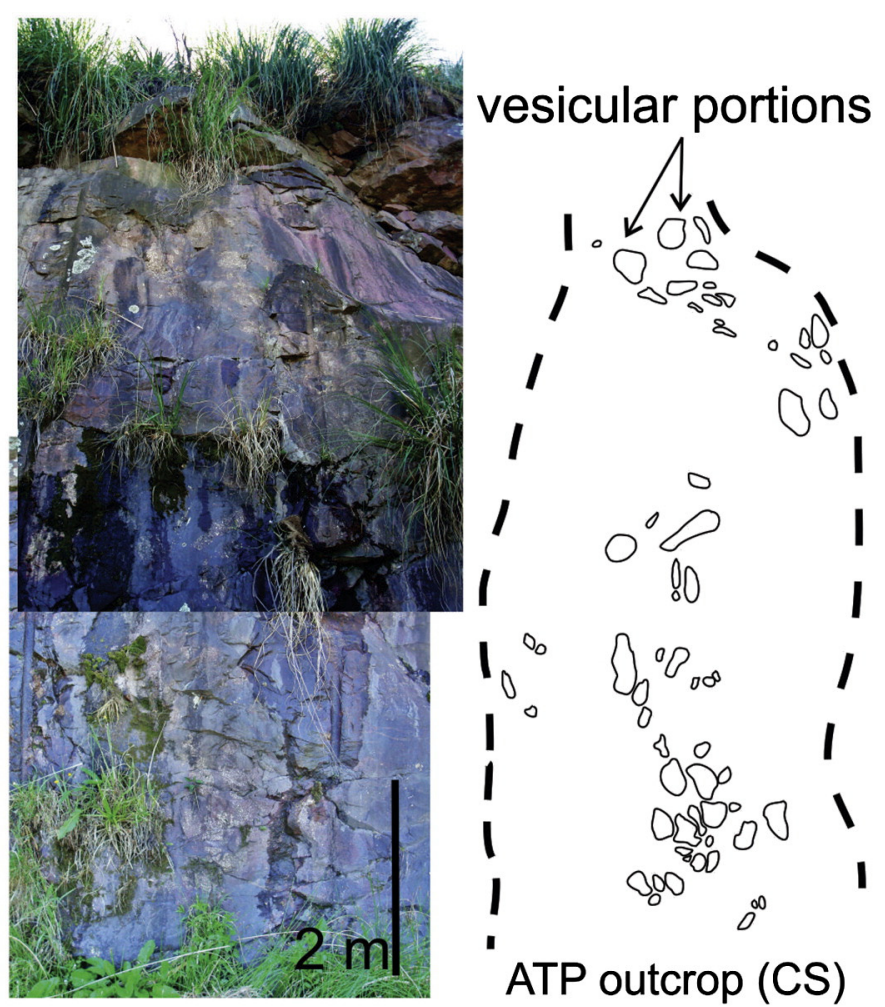

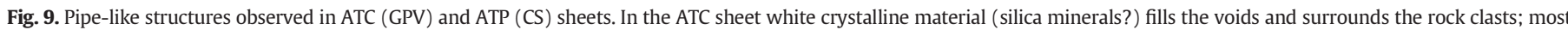
vesicles and amygdales are stretched upwards in the ATP.

embayments produced by resorption. They do not exceed $2 \%$ volume of the rock and are up to $0.5 \mathrm{~mm}$ long with ilmenite also occurring as lamellae in the Ti-magnetite. Apatite amounts to $<1 \%$ volume and longer crystals may reach $0.5 \mathrm{~mm}$. Groundmass crystals-microlites $(<100 \mu \mathrm{m})$ are the same as the phenocrysts except for more evolved plagioclase compositions $\left(\mathrm{An}_{0.02-35}\right)$ and the occurrence of alkali feldspar $\left(\mathrm{Or}_{55-}\right.$ 64). They show tabular, hollow, dendritic, and swallowtail shapes. The groundmass is thoroughly devitrified, ranging from brown spherulitic patches surrounded by microcrystalline material (quartz-feldspar intergrowths) to microgranophyric with quartz-feldspar intergrowths. Phenocrystal clusters (or "glomerocrysts") are also a common feature in these rocks consisting of plagioclase, pyroxene, plagioclase + pyroxene and plagioclase + pyroxene + Fe-Ti oxides assemblages.

ATP rocks are sparsely porphyritic to aphyric with up to 4\% volume of plagioclase (prevailing), pyroxene and Fe-Ti oxide phenomicrophenocrysts. In addition to chemical differences, ATP subtypes also differ with respect to mineralogical assemblages (see Table 1; Figs. 11-12)

Caxias do Sul subtype is characterized by the presence of $\mathrm{Mg}$ orthopyroxene ( $\left.\mathrm{En}_{57-66} \mathrm{Wo}_{3-4}\right)$, with specimens collected in the eastern lower portion (section TA, Fig. 4) containing orthopyroxenes with primarily pigeonite $\left(\mathrm{En}_{44-48} \mathrm{Wo}_{6-8}\right)$ or minor augite rims $\left(\mathrm{En}_{43} \mathrm{Wo}_{37}\right)$ and slightly richer in $\mathrm{FeO}_{\mathrm{t}}$ and $\mathrm{CaO}$ (Fig. 13a) compared to those from eastern upper (section TA) and westernmost portions (section LS, Fig. 4). The Jacuí augite shows $\mathrm{FeO}_{\mathrm{t}}$ content equal or higher than that of Caxias do Sul and the reverse occurs for $\mathrm{MgO}$ content (Fig. 13b). In turn pigeonite of orthopyroxene rims is richer in $\mathrm{FeO}_{\mathrm{t}}$ and poorer in $\mathrm{MgO}$ than Jacuí's pigeonite (Fig. 13c). Caxias do Sul plagioclase displays the highest An content while the Anita Garibaldi and Jacuí (L) have the lowest An content (Fig. 13 d, e). Moreover, the similarity of the An content of these plagioclases (SM, CS and JC subtypes) with those of basalts $\left(\mathrm{An}_{39-81} / \mathrm{av} .=\mathrm{An}_{63}\right.$; Bellieni et al., 1988) and andesites $\left(\mathrm{An}_{31-62} / \mathrm{av} .=\right.$ $\mathrm{An}_{54}$; Bellieni et al., 1988; silicic rocks: $\left.\mathrm{An}_{45-74} / \mathrm{av} .=\mathrm{An}_{56}\right)$ from PMP is noteworthy.
Anita Garibaldi subtype does not contain 'intratelluric' phenocrysts (crystals formed at depth in a magma chamber before magma eruption) as the other subtypes. Instead, its groundmass shows high densities of plag + aug $(+$ pig $)+$ Ti-mag small crystals-to-microlites, which can reach $0.45 \mathrm{~mm}$ (plagioclase) and $0.6 \mathrm{~mm}$ in length (pyroxene) and comprise up to $20 \%$ of rock volume. Thus, these crystals were considered here as groundmass crystals. In the Clevelândia subtype plagioclase and pyroxene (aug + pig) only occur as groundmass small crystalsto-microlites, with lower densities and sizes (up to $250 \mu \mathrm{m}$ long) than the Anita Garibaldi subtype samples. Groundmass assemblages are plag + aug + pig + Ti-mag and plag + aug + Ti-mag (Caxias do Sul, Jacuí and Anita Garibaldi) and plag + pig + Ti-mag (Santa Maria, Caxias do Sul and Clevelândia) with lower An content plagioclase and lower $\mathrm{CaO}$ and $\mathrm{MgO}$ and higher $\mathrm{FeO} \mathrm{w} \%$ pyroxene relatively to the phenocrysts.

Plagioclase phenocrysts make up to $3 \%$ volume of the rock and usually do not exceed $1.5 \mathrm{~mm}$ in length, although larger crystals (up to $3 \mathrm{~mm}$ long), with coarse sieve texture, occur in some of the Caxias do Sul lowermost units and more rarely in the Santa Maria subgroup. Overall, crystals are euhedral-subhedral to rounded with embayments, corroded edges and normal, inverse and oscillatory zoning. Pyroxene phenocrysts represent up to $\sim 1 \%$ volume of the rock, are subhedral to extremely rounded, and rarely reach $1 \mathrm{~mm}$ in length except for some orthopyroxenes exceeding $4 \mathrm{~mm}$ in length. Orthopyroxenes show reacted or corroded edges and partial to complete alteration into a brown or green material. Fe-Ti oxides make up $<1 \%$ and are primarily Ti-magnetite with rare and thin lamellae of ilmenite. Apatite occurs in minute quantities in the groundmass. Phenocrysts are distributed mainly as clusters or glomerocrysts, as in the ATC rocks, in a glassy to thoroughly devitrified groundmass with a broad range in microlite densities. Groundmasses of devitrified samples show brown glassyspherulitic patches surrounded by microcrystalline quartz-feldspar intergrowths to microgranophyric texture throughout. Microlite shapes comprise tabular (laths) to hollow, dendritic, acicular and swallowtail 

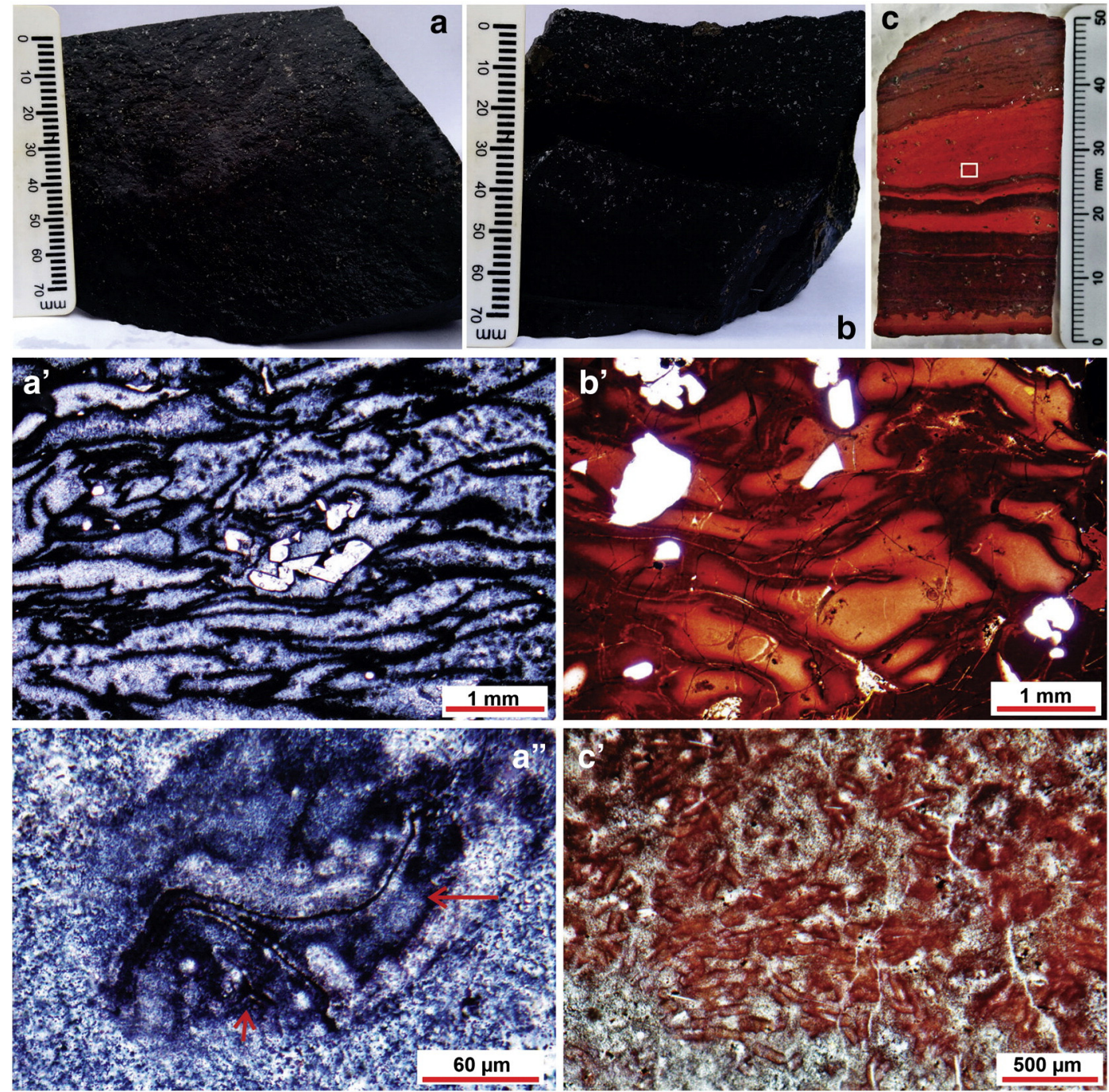

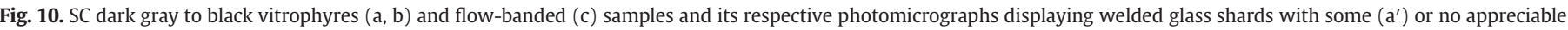

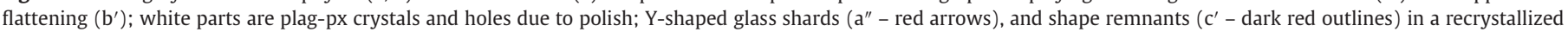
groundmass; the square in $(c)$ indicates the view in $\left(c^{\prime}\right) .\left(a^{\prime}, a^{\prime \prime}\right)$ crossed polars; $\left(b^{\prime}, c^{\prime}\right)$ plane polars.

ends for plagioclase and irregular to acicular (up to $4 \mathrm{~mm}$ long) for pyroxene.

\section{Discussion}

\subsection{High- to extremely high-grade ignimbrites}

Based on all features reported here, we interpret the extensive ATC and ATP sheets as high- to extremely high-grade ignimbrites originated from high mass-flux, pyroclastic fountaining eruptions (Branney and Kokelaar, 1992, 2002), possibly fed by fissure vents. The parent pyroclastic density currents flowed over regional subhorizontal or gently sloping terrains that included varied low to moderate relief and hills.

The wide area covered by these deposits is their most impressive aspect. They show a sheet-like geometry, with lateral extents $\gg 40 \mathrm{~km}$, and possibly $\geq 100 \mathrm{~km}$ in some cases, with surface areas up to $16,000 \mathrm{~km}^{2}$. The stratigraphy (coupled with geochemical and mineralogical data) correlates well with that of the African side, where the Goboboseb 'quartz latite' (equivalent to Jacuí) underlies the Springbok 'quartz latite', equivalent to Caxias do Sul (Milner et al., 1995), and the Fria quartz latite, equivalent to Clevelândia subtype, underlies the Sarusas quartz latite, equivalent to Guarapuava subtype (Marsh et al.,
2001; Ewart et al., 2004). Additional (unpublished) data reinforce this correlation and further corroborate broader extent of these sheets (individual units in the Etendeka can reach up to $8800 \mathrm{~km}^{2}$; Milner et al., 1992).

In the southern region the topography where lava domes crop out is characterized by rounded-convex hills (Fig. 14a), whereas extensive plateaus dominate wide areas in the south and in the central regions (Fig. 14b) where extensive sheets occur.

Breccias are remarkably localized and their absence mainly in basal portions is also a strong indication for an emplacement by pyroclastic density currents rather than viscous lava flows. Main examples of extensive silicic lavas described in the literature show widespread basal breccias (Snake River Plain - Bonnichsen and Kauffman, 1987; Bracks Rhyolite, Trans-Pecos Texas - Henry et al., 1990; Gawler Range Province - Allen et al., 2008).

Glass blobs features (see Luchetti et al., 2017-this issue) differ morphologically from typical fiamme or flattened pumices and suggest that these units are 'hybrids' and not exactly similar to conventional ignimbrites (Cas and Wright, 1987). Thoroughly homogeneous vitrophyres, common at the base of the high-grade ignimbrites from the Snake River Plain (e.g. Branney et al., 2008), suggest extreme conditions of welding (Ross and Smith, 1961) or coalescence following the 


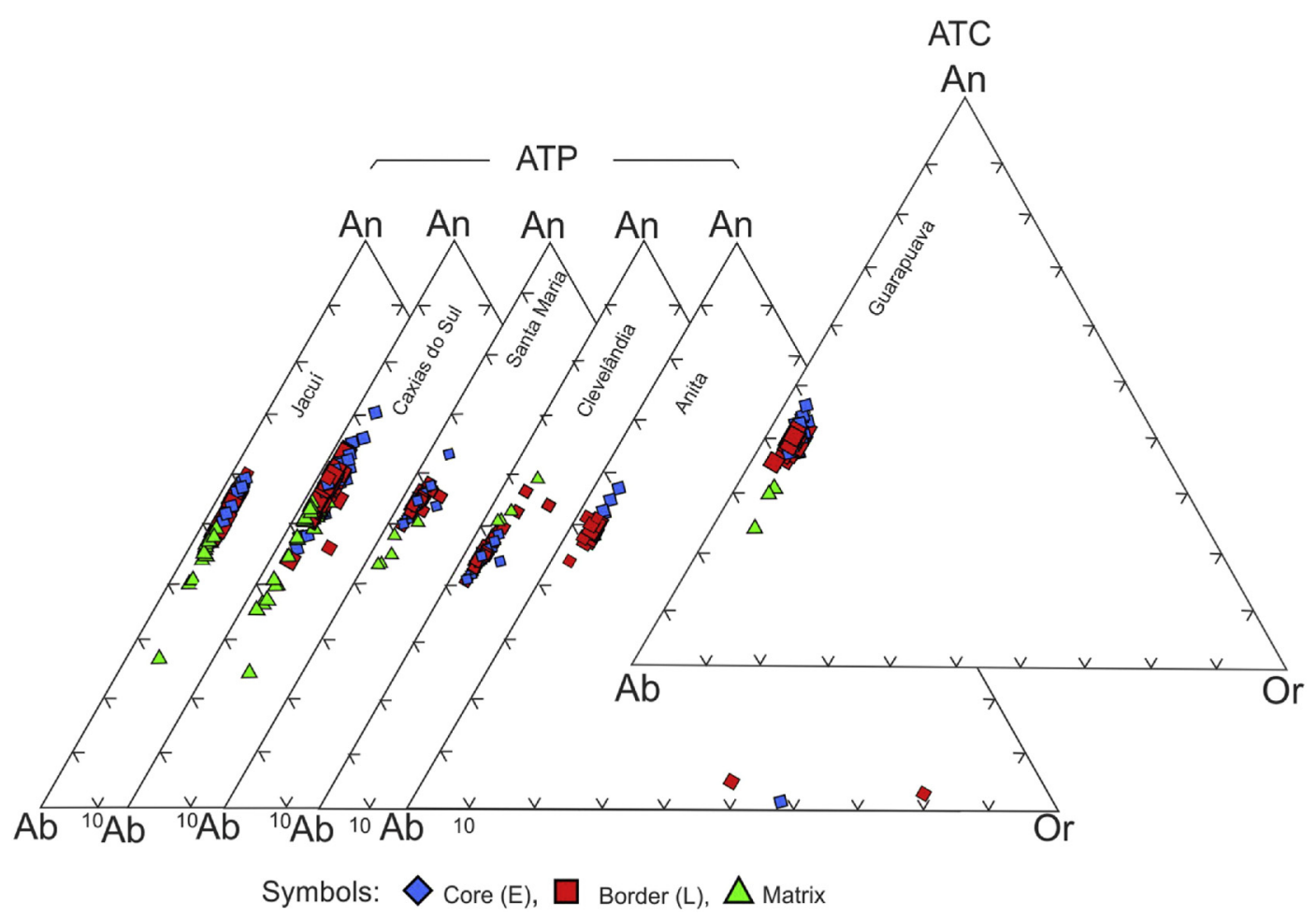

Fig. 11. Ab-An-Or plot of plagioclase crystals. $\mathrm{E}=$ early; $\mathrm{L}=$ late.

ponding of glass particles into a viscous mass with nowhere to flow (Bonnichsen and Citron, 1982; Branney and Kokelaar, 1992). This is consistent with a dominantly flat paleotopography, corresponding to a constructive morphology, produced by the preceding basaltic volcanism, on to which the sheets were emplaced. Moreover the flat topography seems to have played a key role in the bulk deposition, since pervasive secondary flowage structures, commonly seen in many rheomorphic ignimbrites (more easily originated in mass flowage downslope; Bonnichsen and Citron, 1982; Pioli and Rosi, 2005), are found in basal portions or locally comprising the bulk of the sheet (Fig. 7a-c).

Fiamme, bubble wall shards, lithic fragments or broken phenocrysts are seldom observed. However, vitroclastic textures, such as welded glass shards, are unequivocally recognized here and also reported by Garland et al. (1995) and described in the Etendeka quartz latites, by
Milner (1986) and Milner et al. (1992). Also, tuffaceous breccia, blocks and bombs have been recently recognized in a Santa Maria subtype sheet by Riccomini et al. (2016). Further, the vertical and horizontal zoning of phenocryst abundance is also an indication of transport and deposition regimes from granular fluid-based pyroclastic density currents (Branney and Kokelaar, 2002; Branney et al., 2008). Ash fall deposits have not been found or recognized in the PMP and the scarcity of lithic fragments and broken phenocrysts also indicate low explosivity eruptions from relatively hot, fluid and gas poor magmas (Henry and Wolff, 1992).

However, nearly all remaining vestiges of vitroclastic texture may have been pervasively transposed and obliterated by welding, rheomorphism, primary crystallization and subsequent devitrification. Less welded to non-welded facies are either weathered or have been eroded, since exhumation, estimated by apatite fission track, exceeded
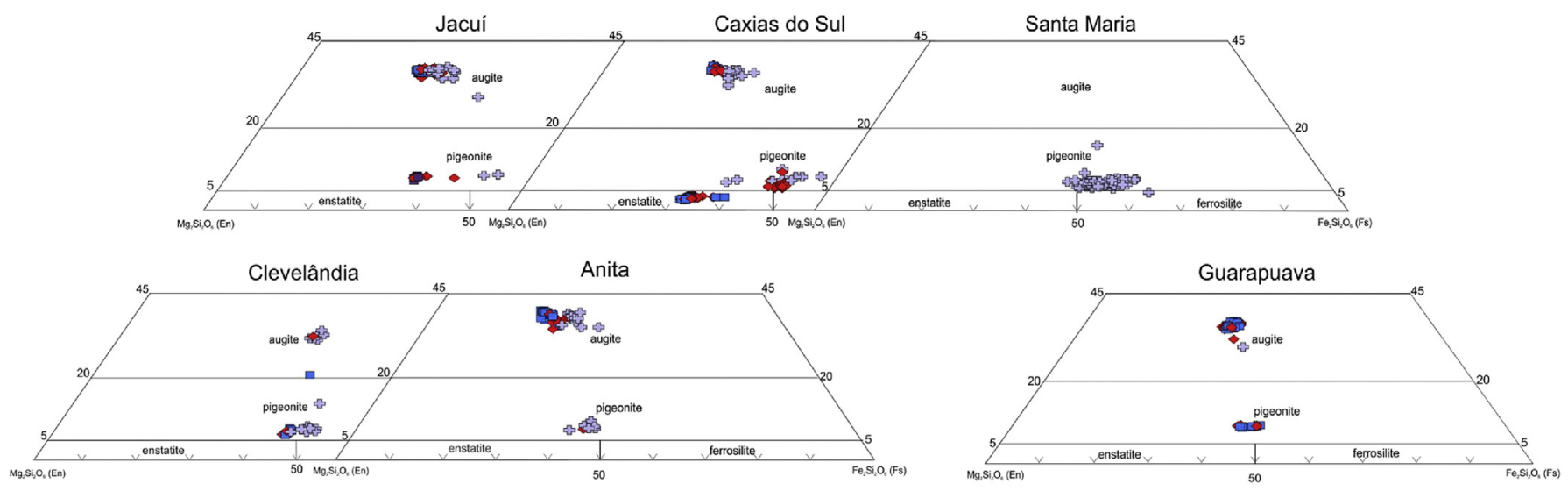

Symbols: $\diamond$ Core (E), $\square$ Border (L). ఓ Matrix

Fig. 12. En-Fs-Wo plot of pyroxene crystals. $\mathrm{E}=$ early; $\mathrm{L}=$ late. 
Table 1

Mineralogical assemblages of ATC and ATP type rocks. Plag = plagioclase; aug = augite; pig = pigeonite; opx = orthopyroxene; $\operatorname{mag}=$ magnetite; ilm = ilmenite; $a p=$ apatite .

\begin{tabular}{cll}
\hline Type & Subtype & Mineralogical assemblage \\
\hline $\begin{array}{c}\text { Chapecó } \\
\text { (ATC) }\end{array}$ & Guarapuava & Plag + aug + pig + mag-ilm + ap \\
Palmas & Clevelândia & Ti-mag \\
(ATP) & Santa Maria & Plag + Ti-mag \\
& Anita & Plag + aug + Ti-mag (microcrystals) \\
& Garibaldi & \\
& Caxias do & Plag + opx + Ti-mag; plag + opx (pig \pm aug rims $)+$ \\
& Sul & aug + Ti-mag; plag + opx + aug + Ti-mag; plag + opx \\
& & (pig rims) + Ti-Mag \\
& Jacuí & Plag + aug + Ti-mag; plag + pig (aug rims) + aug + \\
& & Ti-mag
\end{tabular}

$1 \mathrm{~km}$ (Gallagher et al., 1994). Some sheets remain unsolved, such as the least extensive Jacuí unit. It may represent an extensive silicic lava flow,
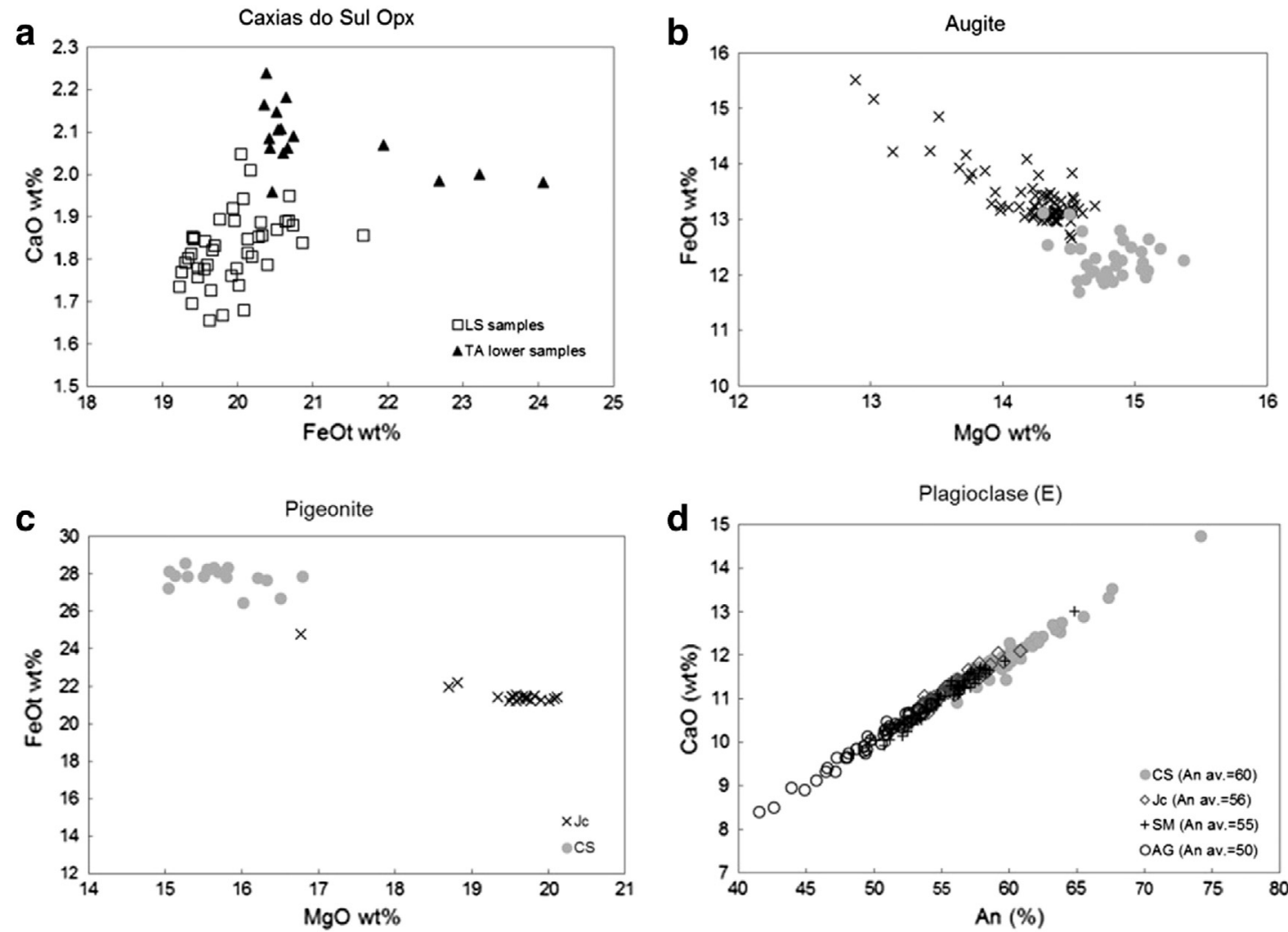

but more detailed studies on this unit are required in order to find pumiceous and/or brecciated carapaces. In the central region, the base of the lower Clevelândia sheet is buried and its top is extremely weathered, but a vesicular-amigdaloidal carapace locally presenting several geodes is recognizable and may indicate a lava flow nature. This pumiceous carapace can be followed for at least $30 \mathrm{~km}$. Nevertheless, for the interpretation of ancient deposits like these, methods such as traditional stratigraphy and petrography may not be sufficient and a comparison with modern similar provinces and experimental volcanology is necessary. Further studies and additional methods, such as those discussed below, may help in the interpretation and clarification of the issue.

\subsection{Intensive parameters}

Temperatures calculated from mineral-liquid equilibrium (Putirka et al., 2003; Putirka, 2005, 2008) show higher $\mathrm{T}\left(1030 \pm 4{ }^{\circ} \mathrm{C}\right)$ for

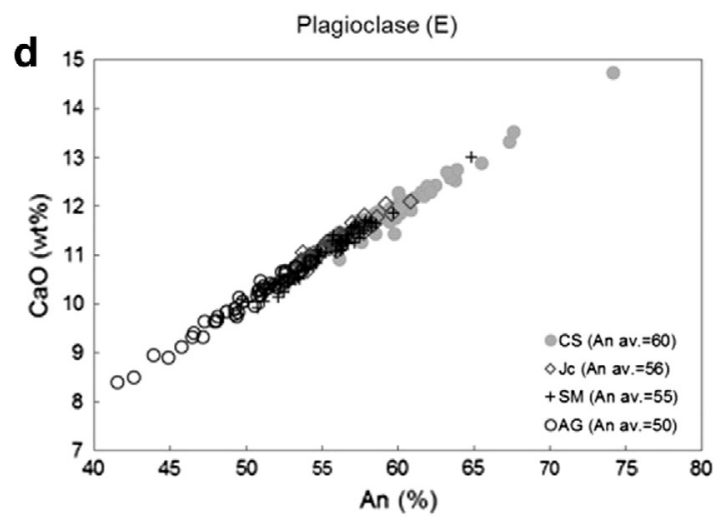

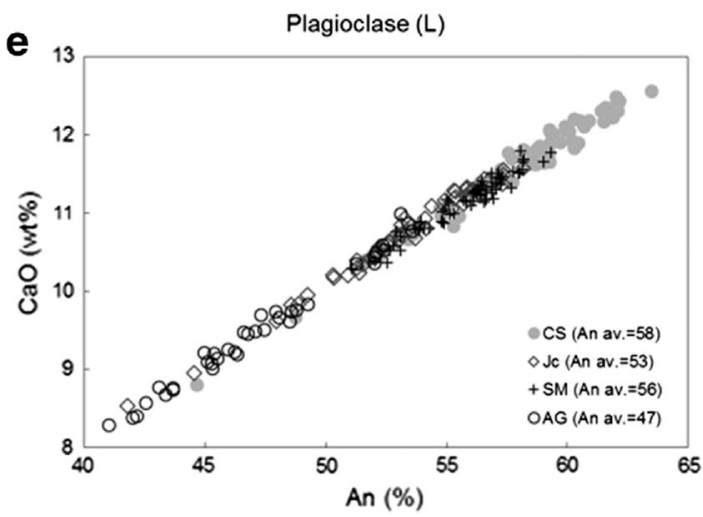

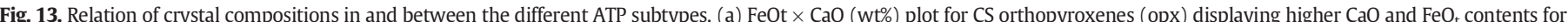

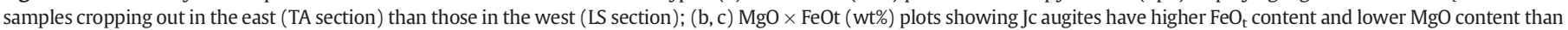

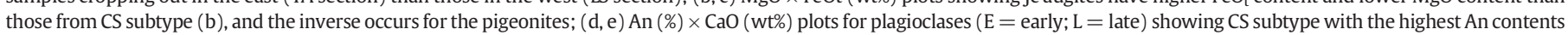
and AG and Jc (L) the lowest An content. 

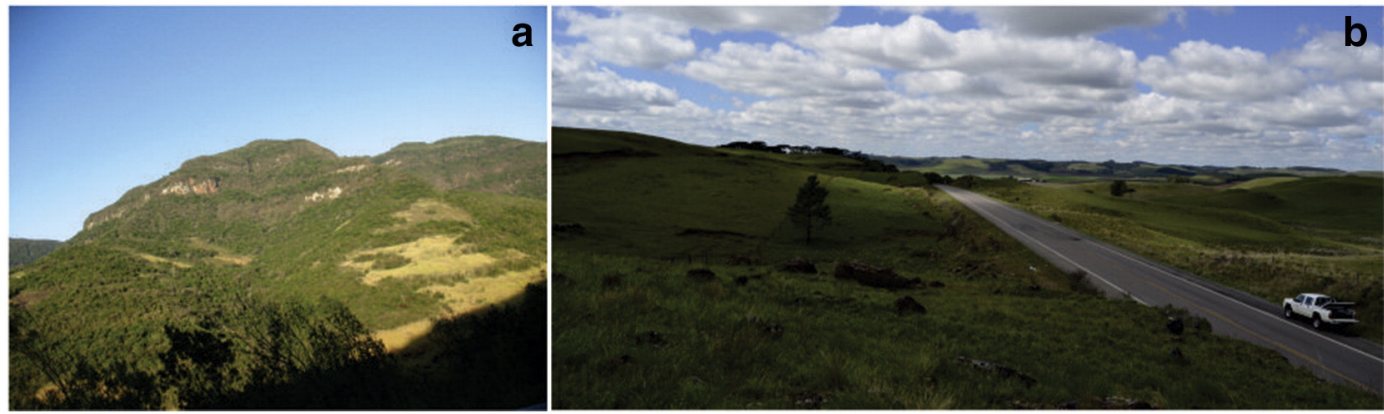

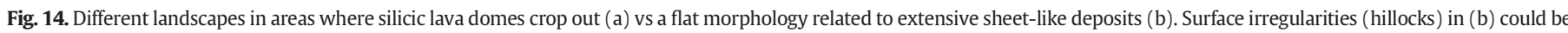
due to differential erosion due to variable welding.

plagioclase than for augite $\left(969 \pm 18^{\circ} \mathrm{C}\right)$ in the ATC magma, suggesting that plagioclase crystallized first. However, augite crystals can be partially or fully included by plagioclase and show strongly rounded to irregular shapes, indicating strong resorption and likely disequilibrium with the host liquid. Therefore, additional studies are needed to clarify the origin of these crystals.

In contrast, ATP pyroxenes show the highest $\mathrm{T}$ in equilibrium with basaltic-to-andesitic liquids $\left(1134 \pm 18{ }^{\circ} \mathrm{C}\right.$ and $1100 \pm 11{ }^{\circ} \mathrm{C}$ average temperatures, respectively), whereas plagioclase indicates a temperature of $976 \pm 2{ }^{\circ} \mathrm{C}$ to $1040 \pm 2{ }^{\circ} \mathrm{C}$ in equilibrium with dacitic liquids. However, augite crystals border some orthopyroxenes and partially or thoroughly enclose plagioclase crystals. These facts may indicate partial melt restites, basic magma recharging, an increase in temperature by a basic magma heating the base of the chamber (Couch et al., 2001), or refractory material that did not melt in the magma chamber (Ellis et al., 2014) and, hence, it will be the focus of future work.

Crystallization depths calculated for pyroxene and plagioclase from ATP rocks reveal shallow storage depths (1-2 kbar), also consistent with the very low $\mathrm{Na}$ and $\mathrm{Al}^{\mathrm{VI}}$ contents of these pyroxenes, while ATC magmas would have been stored at greater depths ( $4 \mathrm{kbar})$.

Both plagioclase hygrometers (SEE - standard errors of estimate $=$ $\pm 1 \%$ ) provided low water contents, $0.6 \mathrm{wt} \%$ for ATC and $0-1.3 \mathrm{wt} \%$ for ATP (using Putirka, 2005 hygrometer) or $1.2 \mathrm{wt} \%$ for ATC and 0.9 1.9 wt\% for ATP rocks (using Putirka, 2008 hygrometer). These estimates are consistent with the anhydrous mineralogy of these rocks, as (1) amphibole is stable in melts containing at least $4 \mathrm{wt} \% \mathrm{H}_{2} \mathrm{O}$ (Rutherford and Hill, 1993); and (2) Barclay and Carmichael (2004) experiments showed that amphibole can crystallize at relatively low water contents (c. 2 wt\% at $\mathrm{P}<50$ to $300 \mathrm{MPa}$ ), and at $1000-1050{ }^{\circ} \mathrm{C}$, amphibole is stable down to at least $2.5 \mathrm{wt} \% \mathrm{H}_{2} \mathrm{O}$. Thus, the absence of amphibole suggests that the maximum water content for these silicic magmas must be low, up to $2 \mathrm{wt} \%$.

Magma viscosities and solubilities were calculated using Giordano et al. (2008) and Zhang et al. (2007) models respectively (Fig. 15). Estimated viscosities of $10^{4-6} \mathrm{~Pa} \mathrm{~s}$ (ATC) and $10^{4-7} \mathrm{~Pa} \mathrm{~s}$ (ATP), at $1000^{\circ} \mathrm{C}$ (using Giordano et al., 2008 model), are considered low for silicic magmas $\left(\sim 10^{\geq 8}\right)$, but up to four orders of magnitude greater than those of mafic lavas with comparable extents (Shaw, 1972). These magmas also would reach water saturation (using Zhang et al., 2007 model) at very shallow levels from $40 \mathrm{MPa}(\sim 1.5 \mathrm{~km})$ for $2 \mathrm{wt} \% \mathrm{H}_{2} \mathrm{O}$ to shallower levels for lower $\mathrm{H}_{2} \mathrm{O}$ contents (Fig. 15b).

\subsection{Eruption-deposition mechanisms}

Magma fragmentation (e.g. Sparks, 1978; Alidibirov and Dingwell, 1996; Dingwell, 1996; Mangan and Cashman, 1996; Mader, 1998; Papale, 1999; Namiki and Manga, 2008; Gonnermann and Manga, 2012; Gonnermann, 2015; Hughes et al., 2017) may involve brittle fragmentation, inertia-driven fragmentation, water-magma interaction, or fragmentation by shear, and such processes predominantly depend on the magma rheology. Thus, brittle failure can occur in viscosities $>10^{6}$ Pa s (Papale, 1999; Namiki and Manga, 2008) or in a fragmentation threshold of $10^{8}$ to $10^{9} \mathrm{~Pa} \cdot \mathrm{s}$ (Papale, 1999), either because: (1) it hinders bubble growth, leading to large tensile stress within the melt surrounding bubbles (Sparks et al., 1994; Toramaru, 1995; Koyaguchi and Mitani, 2005); or (2) because the deformation rate exceeds the inverse relaxation time of the melt (Webb and Dingwell, 1990; Papale, 1999; Gonnermann and Manga, 2003). On the other hand, in viscosities $<10^{6}$ Pa s (Papale, 1999; Namiki and Manga, 2008) the fluid-dynamic (inertia-driven) breakup can occur, as in Hawaiian-style eruptions, in which rapid expansion causes magma stretching into hydrodynamically unstable sheets and filaments (Namiki and Manga, 2008).

Nevertheless, low-viscosity magmas also can explosively fragment in a brittle manner, such as the Chaitén rhyolite $\left(10^{6-8}\right.$ Pa s; Castro and Dingwell, 2009) and magmas with even lower viscosities, such as peralkaline $\left(10^{4-6}\right.$ Pa s; Di Genova et al., 2013; Campagnola et al., 2016; Hughes et al., 2017, in press) and mafic $\left(10^{2-3} \mathrm{~Pa} \mathrm{~s}\right.$; Campagnola et al., 2016) magmas. This process would take place by rapid decompression following edifice collapse (Castro and Dingwell, 2009), rapid decompression associated with rapid ascent and extensive microlite crystallization (Campagnola et al., 2016), or high decompression rates coupled with strain localization and high bubble
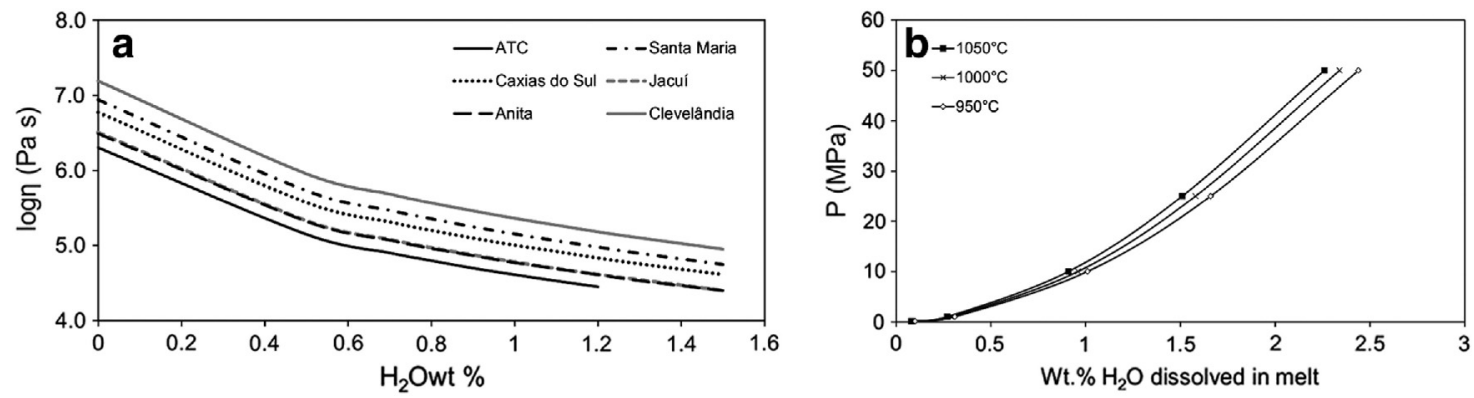

Fig. 15. Magma viscosities at $1000^{\circ} \mathrm{C}$ by Giordano et al. (2008) model (a) and solubilities by Zhang et al. (2007) model (b). 
overpressures (Hughes et al., 2017). Indeed, there is a complex interplay between decompression, exsolution, and crystallization affecting magma rheology in the conduit (Gardner et al., 1996; Gonnermann and Manga, 2012; Campagnola et al., 2016). Furthermore, high decompression rates are also associated with both low viscosity silicic and mafic magmas involving different fragmentation mechanisms, brittle and hydrodynamic (Namiki and Manga, 2008; Gonnermann, 2015; Mangan et al., 2014; Ferguson et al., 2016; Hughes et al., 2017).

Our thermobarometric studies indicate extremely hot ( 950 to $\left.>1000^{\circ} \mathrm{C}\right)$, dry $\left(\leq 2 \mathrm{wt} \% \mathrm{H}_{2} \mathrm{O}\right)$ shallow, voluminous silicic magma bodies. Estimated viscosities are low $\left(10^{4.31}\right.$ to $10^{7.22} \mathrm{~Pa} \mathrm{~s}$, at $\left.1000^{\circ} \mathrm{C}\right)$. These facts, associated with the pyroclasts morphologies described above, such as glass blobs, similar to 'spatters' (Sumner et al., 2005), and globule shards (Milner et al., 1992), common in mafic fire-fountains, as well as blocky, cuspate and Y-shaped shards, suggest a hybrid fragmentation process, between hydrodynamic and brittle behavior.

Therefore, these magma characteristics were responsible for low column height, low explosivity eruptions (Fig. 16a) that preserved the high temperatures and minimized entrainment of accidental lithic clasts. Eruption clouds consisted mainly of a fluidized suspension of near molten droplets and blobs, and an intense welding and local rheomorphism would have followed the deflation of the eruption column. Agglutination or possible coalescence during aggradational deposition (Branney and Kokelaar, 1992, 2002) rather than by postdepositional compaction loading would lead to rapid homogenization (homogeneous pitchstones).

This emplacement model (Fig. 16b) corresponds to that proposed by Branney and Kokelaar $(1992,2002)$ to produce a deposit aggrading during the sustained passage of a pyroclastic density current (hot particles agglutinate and/or coalesce just below a depositional boundary layer that migrates progressively upwards during deposition). Here, a transition from particulate flow (the overriding current) to non-particulate flow occurs. The non-particulate agglutinated or coalesced material, depending on the slope degree, may undergo complex syn- and post-depositional welding and rheomorphism, and flow fabrics, flow folds producing elongation lineations (Branney and Kokelaar, 1992; Branney et al., 2004; Andrews and Branney, 2011). Moreover, the high eruptive temperatures and low glass transition temperatures (507$735^{\circ} \mathrm{C}$ ) estimated for these magmas may have played an important role in the extended welding and rheomorphism, which is characteristic of peralkaline rheoignimbrites (e.g., Wolff and Wright, 1981; Stevenson and Wilson, 1997).

The eruptions must also have involved many simultaneously active vents and high volume fluxes which lead to fast accumulation rates and widespread dispersion of erupted material. Eruption rates are not known in the PMP. Furthermore, volcanism in the PMP is thought to have been predominantly fissural, since caldera structures have not been recognized hitherto. These fissure vents could have facilitate the high discharge rates due to their large cross-sectional area. On the other hand, the circular structure of Messum (Etendeka Province) is assigned as the eruptive center for Goboboseb and Springbok quartz latites (Milner and Ewart, 1989; Milner et al., 1992) which are correlated with the eastern Jacuí and Caxias do Sul units, respectively (Milner et al., 1995). Circular structures recently reported by Riccomini et al. (2016) in the southern region near Soledade, and an intrusive body observed in this present work also indicate the need for further detailed work in order to recognize possible eruptive centers.

In addition, lava domes represent small-volume flows and would express limited effusion rates supplied by small magma chambers, whereas large-volume ignimbrites reflect high magma supply rates tapping

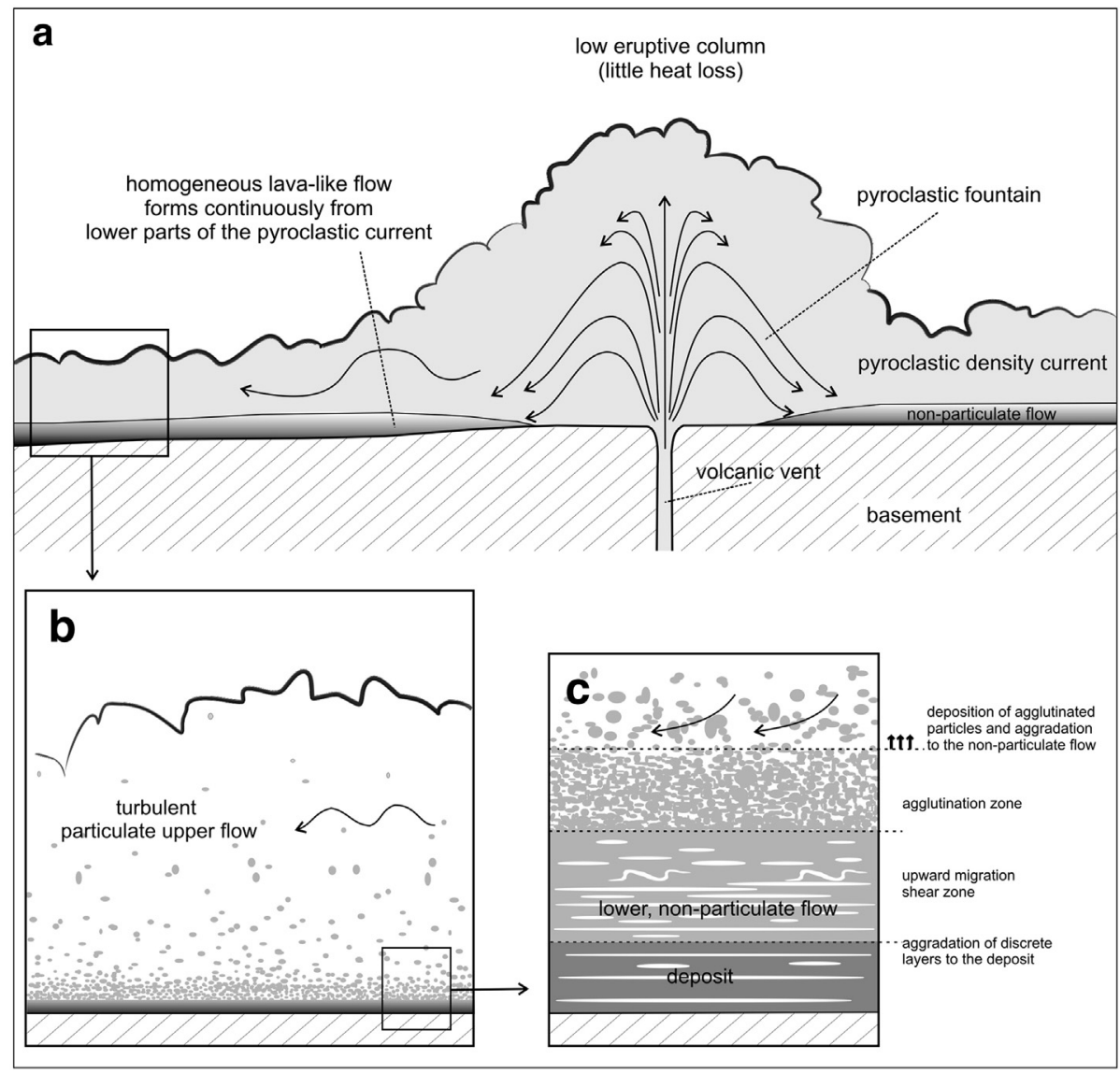

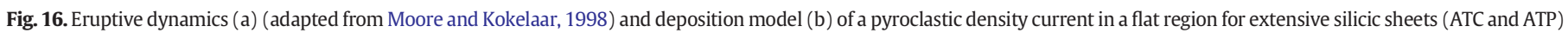
from the PMP (modified from Pioli and Rosi, 2005 and adapted from Branney and Kokelaar, 1992). 
larger magma chambers (Jaupart and Allegre, 1991; Eichelberger et al., 1986; Eichelberger, 1995).

\section{Conclusions}

Silicic volcanism in the Paraná Magmatic Province (PMP) is characterized by lava domes and high- to extremely high-grade ignimbrites (densely welded to lava-like facies). Lava domes are found in the southern region of PMP, where dacites and rhyolites of Palmas type (ATP) crop out, and are characterized mainly by massive pitchstones with an usually altered, vesicular to brecciated carapace, or massive pitchstone interiors wrapped by concentrically jointed, devitrified rock. A silicic body intruded in sandstones was also observed in the same area where the lava domes occur and may represent an exhumed vent.

Large volume ignimbrites comprise trachydacites of Chapecó (ATC) and rhyolites of Palmas (ATP) types in the central region of the PMP; here rhyolites occur interlayered in the basaltic lava flow sequence and are locally overlain by ATC rocks. In the south region, ATP dacites to rhyolites overlie lava domes and basalt flows, and also underlie lava domes in the east. Such a scenario suggests that the silicic volcanism, in part of the southern region, evolved mainly from effusive small volume eruptions to large volume explosive events generating extensive pyroclastic flows. Although uncommon, lava domes may form without being preceded by extensive pyroclastic deposits. This would require some process of previous magma degassing and/or a tensional/ transtensional volcano-tectonic regime allowing degassed magma to reach the surface without prior explosive manifestations (e.g. Zanon and Pimentel, 2015).

The characteristic features of the PMP ignimbrites are:

(1) sheet-like geometries, with lateral extents exceeding $40 \mathrm{~km}$ and eventually reaching $100 \mathrm{~km}$, covering areas up to $\sim 16,000 \mathrm{~km}^{2}$. However if we take into account the quartz latites from Namibia (Etendeka Province), where individual units may cover up to $8800 \mathrm{~km}^{2}$ (Milner et al., 1992), the areal extents are even higher;

(2) Absence of an autobrecciated envelope and basal pumice or ash fall-out layers;

(3) Ubiquitous horizontal to sub-horizontal jointing separated by a few centimetres (sheeting joints) to a few metres, resulting in flaggy outcrops in the field, with vertical joints occasionally present;

(4) massive, structureless to horizontally banded-laminated or strongly contorted flow banded structures;

(5) completely homogeneous or locally flow banded vitrophyres;

(6) vertical and horizontal zoning of phenocryst abundance, decreasing upward and laterally;

(7) densely welded originally glass blobs producing eutaxitic-like texture (Luchetti et al., 2017-this issue);

(8) scarce broken phenocrysts, fiamme and lithic fragments;

(9) Welded blocky, cuspate and Y-shaped glass shards with no appreciable flattening to extremely flattened and stretched recognized in basal portions and vitrophyres.

Eruptions must have been characterized by high mass fluxes, low explosivity favoured by low water content, and low collapsing eruptive columns leading to little heat loss during column collapse, producing high temperature and low viscosity pyroclastic density currents that contributed to welding and/or agglutination of particles (Sparks et al., 1978; Henry and Wolff, 1992; Branney and Kokelaar, 1992).

\section{Acknowledgements}

This study is part of PhD research by ACFL completed at the Institute of Geosciences and Exact Sciences (IGCE), São Paulo State University (UNESP). Funding and in-kind support were provided by National
Council for Scientific and Technological Development (CNPq; PhD grant and support no. 484657/2011-9), Coordination for the Improvement of Higher Education Personnel (CAPES; PDSE-2998/13-0) and São Paulo Research Foundation (FAPESP). We thank Fábio Machado and Francisco Negri for support during strenuous field work and to Marcelo Arnósio, Darren Gravley and Guilherme Gualda for discussions and highly constructive advices. The authors also thank Graham Andrews, C.P. de Campos and an anonymous reviewer for their valuable suggestions that improved the manuscript considerably.

\section{Appendix A. Supplementary data}

Supplementary data to this article can be found online at https://doi. org/10.1016/j.jvolgeores.2017.11.010.

\section{References}

Alberti, A., Piccirillo, E.M., Bellieni, G., Civetta, L., Comin-Chiaramonti, P., Morais, E.A.A 1992. Mesozoic acid volcanics from Southern Angola: petrology, Sr-Nd isotope characteristics, and correlation with the acid stratoid volcanic suites of the Paraná Basin (south-eastern Brazil). Eur. J. Mineral. 4, 597-604.

Alidibirov, M., Dingwell, D.B., 1996. Magma fragmentation by rapid decompression. Nature 380, 146-148.

Allen, S.R., McPhie, J., Ferris, G., Simpson, C., 2008. Evolution and architecture of a large felsic igneous province in western Laurentia: the 1.6 Ga Gawler Range Volcanics, South Australia. J. Volcanol. Geotherm. Res. 172, 132-147.

Andrews, G.D.M., Branney, M.J., 2011. Emplacement and rheomorphic deformation of a large rhyolitic ignimbrite: Grey's Landing, southern Idaho. Geol. Soc. Am. Bull. 123: 725-743. https://doi.org/10.1130/B30167.1.

Andrews, G.D.M., Branney, M.J., Bonnichsen, B., 2008. Rhyolitic ignimbrites in the Rogerson Graben, southern Snake River Plain volcanic province: volcanic stratigraphy, eruption history and basin evolution. Bull. Volcanol. 70, 269-291.

Barclay, J., Carmichael, I.S.E., 2004. A hornblende basalt from western Mexico: water-saturated phase relations constrain a pressure-temperature window of eruptibility J. Petrol. 45, 485-506.

Bellieni, G., Brotzu, P., Comin-Chiaramonti, P., Ernesto, M., Ernesto, M., Melfi, A.J., Pacca, I.G., Piccirillo, E.M., 1984. Flood basalt to rhyolites suites in the southern Paraná plateau (Brazil): paleomagnetism, petrogenis and geodynamic implications. J. Petrol. 25, 579-618.

Bellieni, G., Comin-Chiaramonti, P., Marques, L.S., Melfi, A.J., Nardy, A.J.R., Papatrechas, C., Piccirillo, E.M., Roisenberg, A., 1986. Petrogenetic aspects of acid and basaltic lavas from the Paraná plateau (Brazil): geological, mineralogical and petrochemical relationships. J. Petrol. 27, 915-944.

Bellieni, G., Piccirillo, E.M., Comin-Chiaramonti, P., Melfi, A.J., da Roit, P., 1988. Mineral chemistry of continental stratoid volcanics and related intrusives from the Paraná Basin (Brazil). In: Piccirillo, E.M., Melfi, A.J. (Eds.), The Mesozoic Flood Volcanism of the Paraná Basin: Petrogenetic and Geophysical Aspects. USP, São Paulo, pp. 73-92.

Bonnichsen, B., Citron, G.P. 1982. The Cougar Point Tuff, southwestern Idaho. In: Bonnichsen, B., Breckenridge, R.M. (Eds.), Cenozoic Geology of Idaho. Idaho Bur. Mines. Geol. Bull. 26, pp. 255-281.

Bonnichsen, B., Kauffman, D.F., 1987. Physical features of rhyolite lava flows in the Snake River Plain volcanic province, Southwestern Idaho. Geol. Soc. Am. Spec. Pap. 212 119-145 (Special Paper).

Branney, M.J., Kokelaar, B.P., 1992. A reappraisal of ignimbrite emplacement: changes from particulate to non-particulate flow during progressive aggradation of highgrade ignimbrite. Bull. Volcanol. 54, 504-520.

Branney, M.J., Kokelaar, B.P., 2002. Pyroclastic density currents and the sedimentation of ignimbrites. Geol. Soc. Lond. Mem. 27, 1-152.

Branney, M.J., Kokelaar, B.P., Mcconnell, B.J., 1992. The Bad Step Tuff: a lava-like ignimbrite in a calc-alkaline piecemeal caldera, English Lake District. Bull. Volcanol. 54 187-199.

Branney, M.J., Barry, T.L., Godchaux, M., 2004. Sheathfolds in rheomorphic ignimbrites. Bull. Volcanol. 66, 485-491.

Branney, M.J., Bonnichsen, B., Andrews, G.D.M., Ellis, B., Barry, T.L., Mccurry, M., 2008 'Snake River (SR)-type' volcanism at the Yellowstone hotspot track: distinctive products from unusual, high-temperature silicic super-eruptions. Bull. Volcanol. 70, 293-314.

Bryan, S.E., Ernst, R.E., 2008. Revised definition of large igneous provinces (LIPs). EarthSci. Rev. 86 (1-4):175-202. https://doi.org/10.1016/j.earscirev.2007.08.008.

Bryan, S.E., Ferrari, L., 2013. Large igneous provinces and silicic large igneous provinces: progress in our understanding over the last 25 years. Geol. Soc. Am. Bull. 125 (78), 1053-1078.

Bryan, S.E., Ukstins-Peate, I., Peate, D.W., Self, S., Jerram, D.A., Mawby, M.R., Marsh, J.S Miller, J.A., 2010. The largest volcanic eruptions on Earth. Earth-Sci. Rev. 102 207-229.

Campagnola, S., Romano, C., Mastin, L.G., Vona, A., 2016. Confort 15 model of conduit dynamics: applications to Pantelleria Green Tuff and Etna 122 BC eruptions. Contrib. Mineral. Petrol. 171, 60.

Cas, R.A.F., Wright, J.V., 1987. Volcanic Successions: Modern and Ancient. Alan and Unwin, London (528 pp). 
Castro, J.M., Dingwell, D.B., 2009. Rapid ascent of rhyolitic magma at Chaitén volcano, Chile. Nature 461, 780-783.

Couch, S., Sparks, R.S.J., Carroll, M.R., 2001. Mineral disequilibrium in lavas explained by convective self-mixing in open magma chambers. Nature 411, 1037-1039.

Di Genova, D., Romano, C., Hess, K.-U., Vona, A., Poe, B.T., Giordano, D., Dingwell, D.B Behrens, H., 2013. The rheology of peralkaline rhyolites from Pantelleria Island. J. Volcanol. Geotherm. Res. 249, 201-216.

Dingwell, D.B., 1996. Volcanic dilemma: flow or blow? Science 273, 1054-1055.

Eichelberger, J.C., 1995. Silicic volcanism: ascent of viscous magmas from crustal reservoirs. Annu. Rev. Earth Planet. Sci. 23, 41-63.

Eichelberger, J.C., Carrigan, C.R., Westrich, H.R., Price, R.H., 1986. Non-explosive silicic volcanism. Nature 323:598-602. https://doi.org/10.1038/323598a0.

Ellis, B.S., Bachmann, O., Wolff, J.A., 2014. Cumulate fragments in silicic ignimbrites: the case of the Snake River Plain. Geology 42 (5), 431-434.

Ernesto, M., Raposo, M.I.B., Marques, L.S., Renne, P.R., Diogo, LA., De Min, A., 1999. Paleomagnetism, geochemistry and ${ }^{40} \mathrm{Ar} /{ }^{39} \mathrm{Ar}$ dating of the north-eastern Paraná Magmatic Province. Tectonic implications. J. Geodyn. 28, 321-340.

Ernst, R.E., Buchan, K.L., Campbell, I.H., 2005. Frontiers in large igneous province research. Lithos 79 (3-4):271-297. https://doi.org/10.1016/j.lithos.2004.09.004.

Ewart, A., Marsh, J.S., Milner, S.C., Duncan, A.R., Kamber, B.S., Armstrong, R.A., 2004. Petrology and geochemistry of early cretaceous bimodal continental flood volcanism of the NW Etendeka, Namibia. Part 2: characteristics and petrogenesis of the high-Ti latite and high-Ti and low-Ti voluminous quartz latite eruptives. J. Petrol. 45 (1): 107-138. https://doi.org/10.1093/petrology/egg082.

Ferguson, D.J., Gonnermann, H.M., Ruprecht, P., Plank, T., Hauri, E.H., Houghton, B.F. Swanson, D.A., 2016. Magma decompression rates during explosive eruptions of Kīlauea volcano, Hawaii, recorded by melt embayments. Bull. Volcanol. 78, 71.

Freundt, A., 1998. The formation of high-grade ignimbrites, I: experiments on high- and low-concentration transport systems containing sticky particles. Bull. Volcanol. 59, 414-435.

Freundt, A., Schmincke, H.U., 1995. Eruption and emplacement of a basaltic welded ignimbrite during caldera formation on Gran Canaria. Bull. Volcanol. 56, 640-659.

Gallagher, K., Hawkesworth, C.J., Mantovani, M.S.M., 1994. The denudation history of the onshore continental margin of SE Brazil inferred from apatite fission track data. J. Geophys. Res. 99, 18117-18145.

Gardner, J.E., Thomas, R.M.E., Jaupart, C., Tait, S., 1996. Fragmentation of magma during Plinian volcanic eruptions. Bull. Volcanol. 58, 144-162.

Garland, F., Hawkesworth, C.J., Mantovani, M.S.M., 1995. Description and petrogenesis of the Paraná rhyolites, Southern Brazil. J. Petrol. 36 (5), 1193-1227.

Giordano, D., Russell, J.K., Dingwell, D.B., 2008. Viscosity of magmatic liquids: a model. Earth Planet. Sci. Lett. 271 (1-4), 123-134.

Gonnermann, H., 2015. Magma fragmentation. Annu. Rev. Earth Planet. Sci. 43:431-458 https://doi.org/10.1146/annurev-earth-060614-105206.

Gonnermann, H.M., Manga, M., 2003. Explosive volcanism may not be an inevitable consequence of magma fragmentation. Nature 426, 432-435.

Gonnermann, H.M., Manga, M., 2012. Dynamics of magma ascent in the volcanic conduit In: Fagents, S.A., Gregg, T.K.P. Lopes, R.M.C. (Eds.), Modeling Volcanic Processes, the Physics and Mathematics of Volcanism. Cambridge University Press, pp. 55-84.

Henry, C.D., Wolff, J.A., 1992. Distinguishing strongly rheomorphic tuffs from extensive silicic lavas. Bull. Volcanol. 54, 171-186.

Henry, C.D., Price, J.G., Rubin, J.N., Parker, D.F., Wolff, J.A., Self, S., Franklin, R., Barker, D.S., 1988. Widespread, lava-like silicic volcanic rocks of Trans-Pecos Texas. Geology 16 509-512.

Henry, C.D., Price, J.G., Rubin, J.N., Laubach, S.E., 1990. Case study of an extensive silicic lava: the Bracks Rhyolite, Trans-Pecos Texas. J. Volcanol. Geotherm. Res. 43, 113-132.

Hughes, E.C., Neave, D.A., Dobson, K.J., Withers, P.J., Edmonds, M., 2017. How to fragment peralkaline rhyolites: observations on pumice using combined multi-scale 2D and 3D imaging. J. Volcanol. Geotherm. Res. 336, 179-191.

Janasi, V.A., Freitas, V.A., Heaman, L.H., 2011. The onset of flood basalt volcanism, Northern Paraná Basin, Brazil: a precise U-Pb baddeleyite/zircon age for a Chapecó-type dacite. Earth Planet. Sci. Lett. 302, 147-153.

Jaupart, C., Allegre, C.J., 1991. Gas content, eruption rate and instabilities of eruption regime in silicic volcanoes. Earth Planet. Sci. Lett. 102:413-429. https://doi.org/ 10.1016/0012-821X(91)90032-D.

Kobberger, G., Schmincke, H.U., 1999. Deposition of rheomorphic ignimbrite D (Mogán Formation), Gran Canaria, Canary Islands, Spain. Bull. Volcanol. 60, 455-485.

Koyaguchi, T., Mitani, N.K., 2005. A theoretical model for fragmentation of viscous bubbly magmas in shock tubes. J. Geophys. Res. 110, B10202.

Luchetti, A.C.F., Nardy, A.J.R., Machado, F.B., Madeira, J.E.O., Arnosio, J.M., 2014. New insights on the occurrence of peperites and sedimentary deposits within the silicic volcanic sequences of the Paraná Magmatic Province, Brazil. Solid Earth 5, 121-130.

Luchetti, A.C.F., Gravley, D.M., Gualda, G.A.R., Nardy, A.J.R., 2017. Textural evidence for high-grade ignimbrites formed by low-explosivity eruptions, Paraná Magmatic Province, southern Brazil. J. Volcanol. Geotherm. Res. https://doi.org/10.1016/ j.jvolgeores.2017.04.012 (this issue).

Mader, H.M., 1998. Conduit flow and fragmentation. Geol. Soc. Lond. Spec. Publ. 145, $51-71$.

Mahoney, J.J., Coffin, M.F. (Eds.), 1997. Large igneous provinces: continental, oceanic, and planetary flood volcanism. Am. Geophys. Union, Geoph. Monog. Series vol. 100 (438 pp).

Mangan, M.T., Cashman, K.V., 1996. The structure of basaltic scoria and reticulite and inferences for vesiculation, foam formation, and fragmentation in lava fountains. J. Volcanol. Geotherm. Res. 73, 1-18.

Mangan, M.T., Cashman, K.V., Swanson, D., 2014. The dynamics of Hawaiian-style eruptions: a century of study. In: Poland, M.P., Takahashi, T.J., Landowski, C.M. (Eds.), Characteristics of Hawaiian Volcanoes. U.S. Geol. Surv. Prof. Paper 1801, pp. 323-354.
Marques, L.S., Ernesto, M., 2004. O magmatismo toleítico da Bacia do Paraná. In: Mantesso-Neto, V., Bartorelli, A., Carneiro, C.D.R., Brito-Neves, B.B. (Eds.), Geologia do Continente Sul-Americano. Beca Produções Culturais Ltda, pp. 245-263.

Marsh, J.S., Ewart, A., Milner, S.C., Duncan, A.R., Mcg. Miller, R., 2001. The Etendeka Igneous Province: magma types and their stratigraphic distribution with implications for the evolution of the Parana-Etendeka flood basalt province. Bull. Volcanol. 62, 464-486.

McArthur, A.N., Cas, R.A.F., Orton, G.J., 1998. Distribution and significance of crystalline, perlitic and vesicular textures in the Ordovician Garth Tuff (Wales). Bull. Volcanol. 60, 260-285

Melfi, A.J., Piccirillo, E.M., Nardy, A.J.R., 1988. Geological and magmatic aspects of the Paraná Basin: an introduction. In: Piccirillo, E.M. Melfi, A.J. (Eds.), The Mesozoic Flood Volcanism of the Paraná Basin: Petrogenetic and Geophysical Aspects. USP, São Paulo, pp. 1-14.

Milner, S.C., 1986. The geological and volcanological features of the quartz latites of the Etendeka Formation. Communs Geol. Surv. S.W. Africa/Namibia 2, 101-108.

Milner, S.C., Ewart, A., 1989. The geology of the Goboboseb Mountain volcanics and their relationship to the Messum Complex. Communs. Geol. Surv. Namibia 5, 31-40.

Milner, S.C., Duncan, A.R., Ewart, A., 1992. Quartz latite rheoignimbrite flows of the Etendeka Formation, north western Namibia. B. Volcanol. 54, 200-219.

Milner, S.C., Duncan, A.R., Whittingham, A.M., Ewart, A., 1995. Trans-Atlantic correlation of eruptive sequences and individual silicic volcanic units within the ParanaEtendeka igneous province. J. Volcanol. Geotherm. Res. 69, 137-157.

Mincato, R.L., Enzweiler, J., Schrank, A., 2003. Novas idades 39Ar/40Ar e implicações na metalogênese dos depósitos de sulfetos magmáticos de Ni-Cu-EPG na Província Ígnea Continental do Paraná. 9th Brazilian Congress of Geochemistry, Belém (Pará), Brazil, 2-9 November, pp. 67-92.

Moore, I., Kokelaar, P., 1998. Tectonically controlled piecemeal caldera collapse: a case study of Glencoe volcano, Scotland. Geol. Soc. Am. Bull. 11, 1448-1466.

Namiki, A., Manga, M., 2008. Transition between fragmentation and permeable outgassing of low viscosity magmas. J. Volcanol. Geotherm. Res. 169, 48-60.

Nardy, A.J.R., Enzweiler, J., Bahia Filho, O., de Oliveira, M.A.F., Penereiro, M.A.V., 1997. Determinação de Elementos Maiores e Menores em ROchas Silicáticas por Espectrometria de Fluorescência de Raios-X: Resultados Preliminares. 6 Congresso Brasileiro de Geoquímica, Salvador, BA. Anais vol. 1. Sociedade Brasileira de Geoquímica, Salvador, BA, pp. 346-348.

Nardy, A.J.R., Oliveira, M.A.F., Betancourt, R.H.S., Verdugo, D.R.H., Machado, F.B., 2002. Geologia e estratigrafia da Formação Serra Geral. Rev. Geosci. 21, 15-32.

Nardy, A.J.R., Machado, F.B., Oliveira, M.A.F., 2008. As rochas vulcânicas mesozóicas ácidas da Bacia do Paraná: litoestratigrafia e consideraç̃es geoquímico-estratigráficas. Braz. J. Geol. 38 (1), 178-195.

Papale, P., 1999. Strain-induced magma fragmentation in explosive eruptions. Nature 397, $425-428$.

Peate, D.W., 1997. The Parana-Etendeka Province. In: Mahoney, J.J., Coffin, M.F. (Eds.), Large Igneous Provinces: Continental, Oceanic, and Planetary Flood Volcanism. Am. Geophys. Union, Geoph. Monog. Series vol. 100, pp. 217-246.

Peate, D., Hawkesworth, C.J., Mantovani, M.S.M., 1992. Chemical stratigraphy of the Paraná lavas (South America): classification of magma types and their spatial distribution. Bull. Volcanol. 55, 119-139.

Piccirillo, E.M., Melfi, A.J. (Eds.), 1988. The Mesozoic Flood Volcanism of the Paraná Basin: Petrogenetic and Geophysical Aspects. Instituto Geofísico, Astronômico e Ciências Atmosféricas, Universidade de São Paulo, São Paulo, Brazil (600 pp).

Pinto, V.M., Hartmann, L.S., Santos, J.O.S., Mcnaughton, N.J., Wildner, W., 2010. Zircon U$\mathrm{Pb}$ geochronology from the Paraná bimodal volcanic province support a brief eruptive cycle at $135 \mathrm{Ma}$. Chem. Geol. 28 (2), 93-102.

Pioli, L., Rosi, M., 2005. Rheomorphic structures in a high-grade ignimbrite: the Nuraxi Tuff, Sulcis volcanic district (SW Sardinia, Italy). J. Volcanol. Geotherm. Res. 142, $11-28$.

Polo, L.A., Janasi, V.A., 2014. Volcanic stratigraphy of intermediate to acidic rocks in southern Paraná Magmatic Province, Brazil. Geologia USP Série Científica 14, 83-100.

Polo, L.A., Giordano, D., Janasi, V.A., Guimarães, L.F., 2017. Effusive silicic volcanism in the Paraná Magmatic Province, South Brazil: physico-chemical conditions of storage and eruption and considerations on the rheological behavior during emplacement. J. Volcanol. Geotherm. Res. in press. https://doi.org/10.1016/j.jvolgeores.2017.05.027.

Putirka, K., 2005. Igneous thermometers and barometers based on plagioclase + liquid equilibria: tests of some existing models and new calibrations. Am. Mineral. 90, 336-346.

Putirka, K., 2008. Thermometers and barometers for volcanic systems. Rev. Mineral. Geochem. 69, 61-120.

Putirka, K., Ryerson, F.J., Mikaelian, H., 2003. New igneous thermobarometers for mafic and evolved lava compositions, based on clinopyroxene + liquid equilibria. Am. Mineral. 88, 1542-1554.

Renne, P.R., Ernesto, M., Pacca, I.G., Coe, R.S., Glen, J.M., Prévot, M., Perrin, M., 1992. The age of Parana flood volcanism, rifting of Gondwanaland, and the Jurassic-Cretaceous boundary. Science 258, 975-979.

Renne, P.R., Deckart, K., Ernesto, M., Féraud, G., Piccirillo, E.M., 1996a. Age of the Ponta Grossa dyke swarm (Brazil), and implications to Paraná flood volcanism. Earth Planet. Sci. Lett. 144, 199-211.

Renne, P.R., Glen, J.M., Milner, S.C., Duncan, A.R., 1996b. Age of Etendeka flood volcanism and associated intrusions in southwestern Africa. Geology 24, 659-662.

Riccomini, C., Sant'Anna, L.G., Fambrini, G.L., 2016. The Early Cretaceous Jacuí Group, a newly discovered volcaniclastic-epiclastic accumulation at the top of the Paraná Basin, southern Brazil. Cretac. Res. 59, 111-128.

Ross, C.S., Smith, R.L., 1961. Ash-flow tuffs, their origin, geological relations and identification. US Geol. Surv. Prof. Pap. 366, 1-77. 
Rutherford, M., Hill, P., 1993. Magma ascent rates from amphibole breakdown: an experimental study applied to the 1980-1986 Mount St. Helens eruptions. J. Geophys. Res. 98 (B11), 19667-19685.

Schmincke, H.U., Swanson, D.A., 1967. Laminar viscous flowage structures in ash-flow tuffs from Gran Canaria, Canary Islands. J. Geol. 75, 641-664.

Shaw, H.R., 1972. Viscosities of magmatic silicate liquids: an empirical method of prediction. Am. J. Sci. 272, 870-893.

Sparks, R.S.J., 1978. The dynamics of bubble formation and growth in magmas: a review and analysis. J. Volcanol. Geotherm. Res. 3, 1-37.

Sparks, R.S.J., Wilson, L., Hulme, G., 1978. Theoretical modeling of the generation movement and emplacement of pyroclastic flows by column collapse. J. Geophys. Res. 83, 1727-1739.

Sparks, R.S.J., Barclay, J., Jaupart, C., Mader, H.M., Phillips, J.C., 1994. Physical aspects of magmatic degassing I. Experimental and theoretical constraints on vesiculation. Rev. Mineral. 30, 413-445.

Stevenson, R.J., Wilson, L., 1997. Physical volcanology and eruption dynamics of peralkaline agglutinates from Pantelleria. J. Volcanol. Geotherm. Res. 79 (1-2), 97-122.

Sumner, J.M., Branney, M.J., 2002. The emplacement of a remarkable heterogeneous, chemically zoned and locally lava-like rheomorphic ignimbrite: 'TL' on Gran Canaria. J. Volcanol. Geotherm. Res. 115, 109-138.

Sumner, J.M., Blake, S., Matela, R.J., Wolff, J.A., 2005. Spatter. J. Volcanol. Geotherm. Res. 142, 49-65.

Thiede, D.S., Vasconcelos, P.M., 2010. Paraná flood basalts: rapid extrusion hypothesis confirmed by new ${ }^{40} \mathrm{Ar} /{ }^{39} \mathrm{Ar}$ results. Geology 38 (8), 747-750.

Toramaru, A., 1995. Numerical study of nucleation and growth of bubbles in viscous magma. J. Geophys. Res. 100 (B2), 1913-1931.

Turner, S., Regelous, M., Kelley, S., Hawksworth, C., Mantovani, M.M.S., 1994. Magmatism and continental break-up in the South Atlantic: high precision ${ }^{40} \mathrm{Ar} /{ }^{39} \mathrm{Ar}$ geochronology. Earth Planet. Sci. Lett. 121, 333-348.

Umann, L.V., Lima, E.F., Sommer, C.A., De Liz, J.D., 2001. Vulcanismo ácido da região de Cambará do Sul-RS: litoquímica e discussão sobre a origem dos depósitos. Rev. Bras. Geosci. 31 (3), 357-364.
Waichel, B.L., Lima, E.F.De, Viana, A.R., Scherer, C.M., Bueno, G.V., Dutra, G., 2012. Stratigraphy and volcanic facies architecture of the Torres Syncline, Southern Brazil, and its role in understanding the Paraná-Etendeka Continental Flood Basalt Province. J. Volcanol. Geotherm. Res. 215-216, 74-82.

Walker, G.P.L., 1983. Ignimbrite types and ignimbrite problems. J. Volcanol. Geotherm Res. 17, 65-88.

Webb, S.L., Dingwell, D.B., 1990. Non Newtonian rheology of igneous melts at high stresses and strain rates: Experimental results for rhyolite, andesite, basalt and nephelinite. J. Geophys. Res. 95, 15695-15701.

White, R.V., Saunders, A.D., 2005. Volcanism, impact and mass extinctions: incredible or credible coincidences? Lithos 79:299-316. https://doi.org/10.1016/ j.lithos.2004.09.016.

White, J.D.L., Bryan, S.E., Ross, P.-S., Self, S., Thordarson, T., 2009. Physical volcanology of continental large igneous provinces: update and review. In: Thordarson, T., Self, S. Larsen, G., Rowland, S.K., Hoskuldsson, A. (Eds.), Studies in Volcanology: The Legacy of George Walker. Special Publications of IAVCEI, 2. Geol. Soc. London, pp. 291-321.

Whittingham, A.M., 1989. Geological features and geochemistry of the acid units of the Serra Geral Formation, south Brazil. Continental Magmatism, Santa Fé IAVCEI Abstracts. New Mexico Bureau of Mines \& Mineral Resources, Santa Fé, New Mexico, USA, p. 293.

Wignall, P.B., 2001. Large igneous provinces and mass extinctions. Earth Sci. Rev. 53:1-33. https://doi.org/10.1016/S0012-8252(00)00037-4.

Wolff, J.A., Wright, J.V., 1981. Rheomorphism of welded tuffs. J. Volcanol. Geotherm. Res. $10,13-34$.

Zanon, V., Pimentel, A., 2015. Spatio-temporal constraints on magma storage and ascent conditions in a transtensional tectonic setting: the case of the Terceira Island (Azores). Am. Mineral. 100, 795-805.

Zhang, Y., Xu, Z., Zhu, M., Wang, H., 2007. Silicate melt properties and volcanic eruptions. Rev. Geophys. 45, 1-27. 